Article

\title{
Performance of Foundry Sand Concrete under Ambient and Elevated Temperatures
}

\author{
Hazrat Bilal 1,2,*俄, Muhammad Yaqub ${ }^{2}$, Sardar Kashif Ur Rehman ${ }^{3, *} \mathbb{C}^{\circ}$, Muhammad Abid 1,4,*, \\ Rayed Alyousef ${ }^{5}{ }^{(\mathbb{D}}$, Hisham Alabduljabbar ${ }^{5}$ and Fahid Aslam ${ }^{5}$ \\ 1 Department of Civil Engineering, City University of Science \& Information Technology, \\ Peshawar 25000, Pakistan \\ 2 Department of Civil Engineering, University of Engineering \& Technology, Taxila 47050, Pakistan \\ 3 Department of Civil Engineering, COMSATS University Islamabad, Abbottabad Campus, \\ Abbottabad 22060, Pakistan \\ 4 College of Aerospace and Civil Engineering, Harbin Engineering University, Harbin 150090, China \\ 5 Department of Civil Engineering, College of Engineering in Al-Kharj, Prince Sattam bin Abdulaziz \\ University, Al-Kharj 11942, Saudi Arabia \\ * Correspondence: hazratbilal@cusit.edu.pk (H.B.); skashif@cuiatd.edu.pk (S.K.U.R.); \\ abid.khg@cusit.edu.pk (M.A.)
}

Received: 13 July 2019; Accepted: 17 August 2019; Published: 20 August 2019

check for updates

\begin{abstract}
Waste foundry sand (WFS) is the by-product of the foundry industry. Utilizing it in the construction industry will protect the environment and its natural resources, and enable sustainable construction. WFS was employed in this research as a fractional substitution of natural sand by $0 \%$, $10 \%, 20 \%, 30 \%$, and $40 \%$ in concrete. Several tests, including workability, compressive strength (CS), splitting tensile strength (STS), and flexural strength (FS), ultrasonic pulse velocity (USPV), Schmidt rebound hammer number (RHN), and residual compressive strengths (RCS) tests were performed to understand the behavior of concrete before and after exposure to elevated temperatures. Test findings showed that the strength characteristics were increased by including WFS at all the phases. For a substitute rate of $30 \%$, the maximum compressive, splitting tensile, and flexural strength were observed. Replacement with WFS enhanced the 28-day compressive, splitting tensile, and flexural strength by $7.82 \%, 9.87 \%$, and $10.35 \%$, respectively at a $30 \%$ replacement level, and showed continuous improvement until the age of 91 days. The RCS of foundry sand concrete after one month of air cooling at ambient temperature after exposing to $300^{\circ} \mathrm{C}, 400^{\circ} \mathrm{C}, 500{ }^{\circ} \mathrm{C}, 600{ }^{\circ} \mathrm{C}, 700{ }^{\circ} \mathrm{C}$, and $800{ }^{\circ} \mathrm{C}$ was found to be in the range of $67.50 \%$ to $71.00 \%, 57.50 \%$ to $61.50 \%, 49.00 \%$ to $51.50 \%, 38 \%$ to $41 \%$, $31 \%$ to $35 \%$ and $26 \%$ to $31.5 \%$ of unheated compressive strength values for $0 \%$ to $40 \%$ replacement of WFS, respectively. The RCS decreases with increasing temperature; however, with increasing WFS, the RCS was enhanced in comparison to the control samples. In addition, the replacement of 30\% yielded excellent outcomes. Hence, this study provides a sustainable construction material that will preserve the Earth's natural resources and provide a best use of WFS.
\end{abstract}

Keywords: foundry sand concrete; strength properties; ultrasonic tests; elevated temperatures; residual compressive strength; explosive spalling

\section{Introduction}

The construction industry plays a vital role in the economic development of any country. Concrete can be classified as the most abundantly used material of the construction industry. The only material used more than concrete by man is water [1]. Currently, concrete is a ubiquitously used construction material (20-35 billion tons annually usage) in the world. Its demand is increasing gradually because 
of its numerous useful properties, such as excellent resistance to water, its ability to mold into various forms and sizes, affordability, high strength, and durability. Moreover, fire resistance is the single most unique yet distantly observed aspect of concrete [1-3]. Raw materials for concrete are obtained from natural resources which are depleting at a fast rate and also lead to the degradation of the natural environment. As the construction industry consumes a large amount of naturally available material, sustainable development in the construction industry is quite important [4,5]. Thus, the alternative is the utilization of industrial by-products and solid wastes such as waste foundry sand, bottom ash, slag, silica fume, and fly ash in producing concrete. The utilization of industrial by-products or waste materials in concrete compensates for the lack of natural resources, solving the disposal problems and creating a way to find the alternative technique to save natural resources.

Foundry sand is a molding sand that is used by the foundry industry owing to its easy accessibility, low cost, heat damage resistance, and bonding with other binders and organic materials. This sand is quite higher in quality than natural sand. Foundry industries utilize this sand time and again. When this sand remains no longer able to be used further in foundry industries, then it is removed and termed as waste foundry sand (WFS). Waste foundry sand is also referred to as used foundry sand (UFS) or spent foundry sand (SFS) [6]. Fine particles in UFS are good enough. The type of metal that is to be poured is responsible for its physical and chemical properties, and even these properties can be changed from one foundry to another with a slight difference. There are two types of foundry sand: One is named as Clay-bonded (Green sand) and the other one is named as chemically bonded sand. Metal casting foundries in the U.S. dispose of about nine million tons of spent sand in landfills per year [7]. According to the industry estimates, almost $100 \times 10^{6}$ tons of foundry sand is used in production in a year; out of this amount, about four to seven million tons are wasted per annum and offered for recycled use [8,9].

Numerous researchers investigated the use of used foundry sand in various civil engineering applications such as highway applications [10], controlled low-strength material [11], and in hot mix asphalt concrete [12]. Numerous researchers have testified the usage of WFS in concrete as a fractional substitution of fine aggregates [13-19].

Siddique et al. $[13,14]$ evaluated the effective use of WFS. In this research study, normal sand was replaced with WFS by $10 \%$ to $30 \%$ at an increment of $10 \%$. Tests of compressive, splitting tensile, and flexural strengths were performed after 28 and 56 days [13]. Similarly, the compressive, splitting tensile, flexural strength, and modulus of elasticity tests were determined after 28, 56, 91, and 365 days [14]. The incorporation of WFS as a fractional substitution up to 30 led to an increase in compressive strength (CS), splitting tensile strength (STS), the modulus of elasticity, and flexural strength (FS). The optimum substitution level of fine aggregates with WFS was found to be $30 \%$. Siddique et al. [15] examined the effect of WFS on concrete compressive strength and splitting tensile strengths at 28, 90, and 365 days of age. The proportion of fine aggregate replaced ranged from $0 \%$ to $60 \%$ at the increment of $10 \%$. Cubes of $150 \mathrm{~mm}$ and cylindrical specimens of $150 \times 300 \mathrm{~mm}$ sizes were used to find the compressive strength and splitting tensile strengths at all ages, respectively. A $30 \%$ substitution of fine aggregate with WFS was found to be optimum, with a precaution that general replacement should not exceed a 50\% replacement level. The incremental trend in compressive and splitting tensile strengths were observed with the age also. Increases of $24.03 \%, 19.23 \%$, and $14.23 \%$ in splitting tensile strengths for $30 \%, 40 \%$, and $50 \%$ respectively were observed, while $4.62 \%$ and $2.39 \%$ increments were observed in compressive strength for $30 \%$ and $40 \%$ replacement levels, respectively, at the age of 28 days. Increases of $25.18 \%, 22.55 \%$, and $19.92 \%$ in splitting tensile strengths for $30 \%, 40 \%$, and $50 \%$, respectively were observed at the age of 90 days. Siddique et al. [16] assessed the properties of two different (M20 and M30) grades of concrete in which WFS was partially replaced with natural sand by $(0-20 \%)$, with an incremental interval of $5 \%$.

In the previous study, Khatib et al. [20] substituted WFS in various quantities for fine aggregate in plain concrete-i.e., from $0 \%$ to $100 \%$ by an incremental interval of $20 \%$-and witnessed a continuous slump loss, as well as a loss of mechanical properties. Based on the type of metal, binder, and 
combustible used, the chemical composition may vary up to some extent, and its efficiency may also be affected. Salokhe et al. [21] found that in case of strength gain, concrete produced with WFS from ferrous foundries performs better than concrete with nonferrous WFS. The water absorption capability depends on the carbon content; more water with high carbon content will be absorbed. Similarly, different authors have reported its behavior in concrete with different results. Siddique et al. [22] determined that similar to plain concrete, the compressive strength of self-compacting concrete also improved by replacing WFS with normal sand by up to $15 \%$. Pathariya et al. [23] reported that a mixture of $60 \%$ WFS showed maximum strength. Siddique et al. [15] stated that at 28 days, 56 days, and 365 days of curing, the strengths of concrete mixes with $30 \%, 40 \%$, and $50 \%$ WFS exceeds that of the control mix. Etxeberria et al. [24] examined concrete made with two qualities of WFS that were named green and chemical foundry sand and evaluated that both concrete samples possess more satisfactory strength than reference concrete at a high water to cement $(\mathrm{w} / \mathrm{c})$ ratio. Incremental trend in strength of concrete with the inclusion of WFS was observed by several researchers, and the author's current study is in line with these researchers [13-15,17,25-27].

Compressive, splitting tensile strengths and flexural strengths tests were measured at the ages of $7,28,56,91$, and 365 days, and noticed an incremental trend of up to $15 \%$ replacement level for mutual (M20 and M30) grades of concrete. Ultrasonic pulse velocity (USPV) tests were evaluated at 28, 91, and 365 days of age. Ultrasonic pulse velocity (USPV) values also exhibited increment in values, with an increment in replacement level up to $15 \%$. Singh and Siddique et al. $[17,18]$ evaluated the strength and durability aspects of concrete prepared with a partial replacement of natural sand with spent foundry sand with $0-20 \%$ dosage, with an incremental interval of $5 \%$. Strength aspects, i.e., the compressive strength, splitting tensile strength, and modulus of elasticity tests and durability aspects i.e., ultrasonic pulse velocity tests, rapid chloride permeability tests, and abrasion resistance tests were carried out. Compressive strengths, splitting tensile strengths, and the modulus of elasticity tests were performed at the age of 7,28, and 91 days. An ultrasonic pulse velocity test was performed at 28 days and 91 days of age. Results showed a slight rise in concrete strength and durability by adding WFS as a fractional substitute of sand up to a substitutional level of $15 \%$. Dash Kumar et al. [19] reported the effective utilization of waste foundry sand in concrete, and concluded that WFS can be effectively utilized as a substitution of fine aggregate up to $20 \%$ without compromising the mechanical and physical properties. The inclusion of waste foundry sand increase the value for ultrasonic pulse velocity, which is an indication of good density, homogeneity, and uniformity of concrete.

The residual strength of hardened concrete after fire when it cools down changes depending upon the maximum temperature attained, mix proportion, aggregate type, fire exposure intensity, and duration of fire [28-30]. Greater reduction would be occurred in the residual compressive strength at the higher rate of cooling [29]. Lee et al. [30] observed a rapid drop in compressive strength at temperature level above $400{ }^{\circ} \mathrm{C}$. Residual compressive strength at $600{ }^{\circ} \mathrm{C}$ and $800{ }^{\circ} \mathrm{C}$ was $57 \%$ and $18 \%$ of the unheated samples, respectively. The failure at higher temperature is because of the development of cracks, variations in the chemistry, and an increase in internal pore pressure as a result of the evaporation of water [31,32]. Arioz et al. [33] reported that the compressive strength, ultrasonic pulse velocity, and rebound number decrease with any increase in temperature. A slight reduction was observed until a temperature of $400{ }^{\circ} \mathrm{C}$, and sharp reduction was observed beyond $400{ }^{\circ} \mathrm{C}$. The longer the exposure duration to elevated temperatures, the larger the fall in compressive strength due to the crack's development and material decay. Most of the strength drop-down happens within the period of the first 30 days of long-term exposure [34].

Chang et al. [35] used concrete cylindrical specimens of size $150 \times 300 \mathrm{~mm}$ to observe the influence of elevated temperatures on compressive strength. Cylindrical specimens were exposed to temperature levels in the range of 200 to $800{ }^{\circ} \mathrm{C}$ with an increment of $200{ }^{\circ} \mathrm{C}$. The residual compressive strength at $200,400,600$, and $800{ }^{\circ} \mathrm{C}$ was $90 \%, 65 \%, 40 \%$, and $15 \%$ of the unheated samples, correspondingly. Hager [36] found that a decrease in strength of concrete starts at $300^{\circ} \mathrm{C}$. Beyond $400{ }^{\circ} \mathrm{C}$, the strength decreases more rapidly due to the degradation of calcium silicate hydrate (CSH) gel. After $900{ }^{\circ} \mathrm{C}$, 
$\mathrm{CSH}$ breaks down completely, so the temperature range of 400 to $900{ }^{\circ} \mathrm{C}$ is the critical temperature range for concrete compressive strength.

The already published literature such as Bhardwaj et al. [37], Bradshaw et al. [38], and Mavroulidou et al. [39] and other researchers such as [13-15,17,25-27] performed many tests on concrete comprising WFS as a partial replacement of sand at ambient temperatures. Since the elevated temperature is a catastrophic phenomenon, the behavior of WFS concrete should be evaluated under elevated temperatures. So, the published literature lacks studies related to effect of elevated temperatures on foundry sand concrete, regarding its resistance to fire in terms of spalling and residual compressive strength after exposure to fire/elevated temperatures. According to the author's knowledge, the behavior of WFS concrete after exposure to elevated temperature has rarely been evaluated. The main objective of this research work is to explore the behavior of WFS concrete under elevated temperatures and compare the behavior of WFS concrete under elevated temperatures and ambient temperatures. Residual compressive strength after exposure to elevated temperature and resistance against fire in terms of a spalling phenomenon has been carefully evaluated.

\section{Research Material}

\section{Materials and Mix Proportions}

Ordinary Portland cement (OPC, Type I) was provided by the Fauji cement company in Pakistan with the chemical composition and physical properties complying with the standard specification of ASTM C-150 [40]. The chemical composition of OPC used in mix is given in Table 1, while the local available sand of Lawrencepur with a nominal size of $4.75 \mathrm{~mm}$ was used as fine aggregate. Local available Margalla crushed angular aggregate of 19-mm size was used as a nominal maximum size of coarse aggregate. The properties of fine and coarse aggregates were found to confirm the requirements of ASTM C-33 [41]. Locally available WFS was used as a fractional substitution of fine aggregates. Foundry sand fineness modulus and bulk density was observed to be lower than that of natural sand. The chemical properties of foundry sand are shown in Table 2. Sieve analysis and the physical properties of aggregates are shown in Figures 1 and 2, and Table 3.

Table 1. Chemical composition (CC) and physical properties of Portland cement.

\begin{tabular}{cccc}
\hline \multicolumn{2}{c}{ Chemical Composition of Cement } & \multicolumn{2}{c}{ Physical Properties of Cement } \\
\hline Components & Content (\%) & Parameter & Value \\
\hline $\mathrm{CaO}$ & 63.47 & Specific Surface & $322 \mathrm{~m}^{2} / \mathrm{kg}$ \\
$\mathrm{SiO}_{2}$ & 22.00 & Consistency & $29 \%$ \\
$\mathrm{Al}_{2} \mathrm{O}_{3}$ & 5.50 & Initial Setting Time & $1 \mathrm{~h}$ and $42 \mathrm{~min}$ \\
$\mathrm{MgO}$ & 1.70 & Final Setting Time & $3 \mathrm{~h}$ and $55 \mathrm{~min}$ \\
$\mathrm{SO}_{3}$ & 1.82 & Specific Gravity & 3.05 \\
$\mathrm{Fe}_{2} \mathrm{O}_{3}$ & 3.50 & - & - \\
$\mathrm{Na}_{2} \mathrm{O}$ & 0.20 & - & - \\
$\mathrm{K}_{2} \mathrm{O}$ & 1.00 & - & - \\
\hline
\end{tabular}


Table 2. Chemical composition (CC) of waste foundry sand.

\begin{tabular}{ccc}
\hline Component & Contents (\%) & Requirements as per American Foundry Men's Society, 1991 \\
\hline $\mathrm{SiO}_{2}$ & 88.50 & $87.9 \%$ \\
$\mathrm{Al}_{2} \mathrm{O}_{3}$ & 4.63 & $4.70 \%$ \\
$\mathrm{Fe}_{2} \mathrm{O}_{3}$ & 0.83 & $0.94 \%$ \\
$\mathrm{MgO}$ & 0.21 & $0.30 \%$ \\
$\mathrm{CaO}$ & 0.90 & $0.14 \%$ (Min.) \\
$\mathrm{Na}{ }_{2} \mathrm{O}$ & 0.02 & - \\
$\mathrm{K}_{2} \mathrm{O}$ & 0.01 & - \\
Sulphates & 0.03 & $0.09 \%$ \\
Loss of Ignition (LOI) & 4.37 & $5.15 \%$ (max.) \\
\hline
\end{tabular}

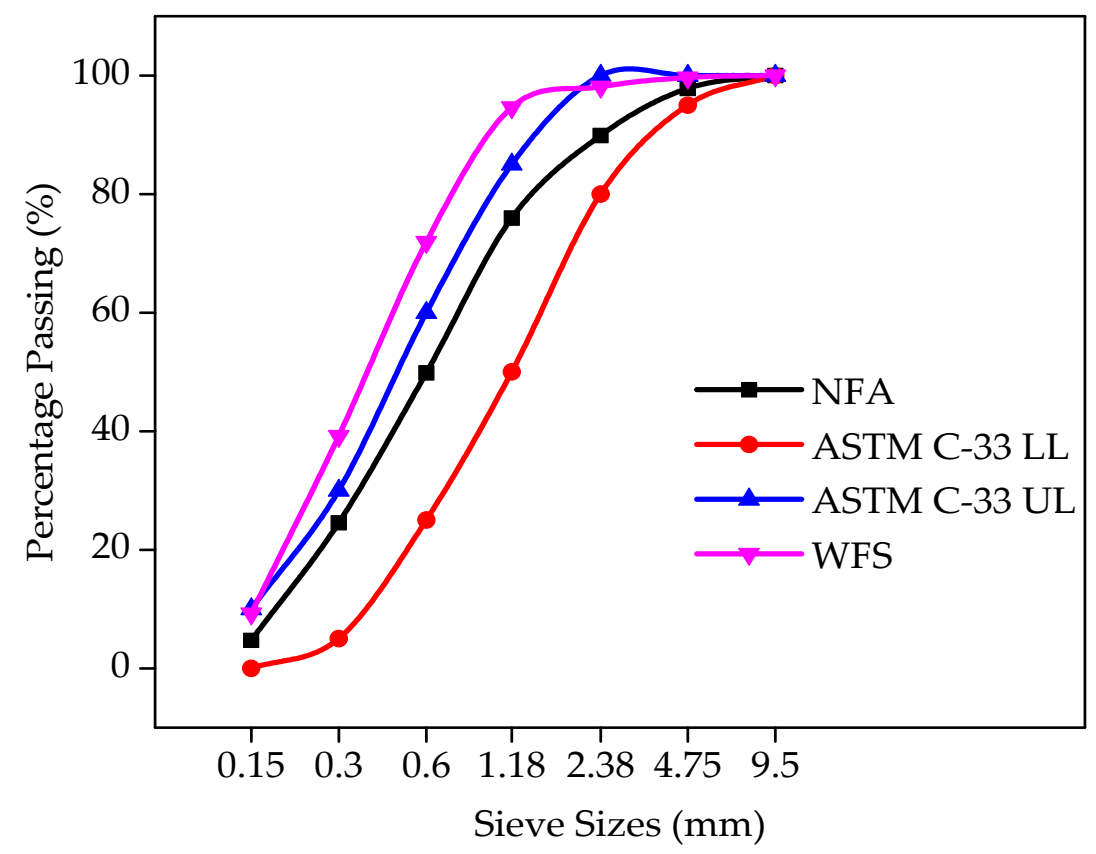

Figure 1. Sieve analysis results of natural fine aggregate (NFA) and waste foundry sand (WFS) in line with ASTM C-33 limits.

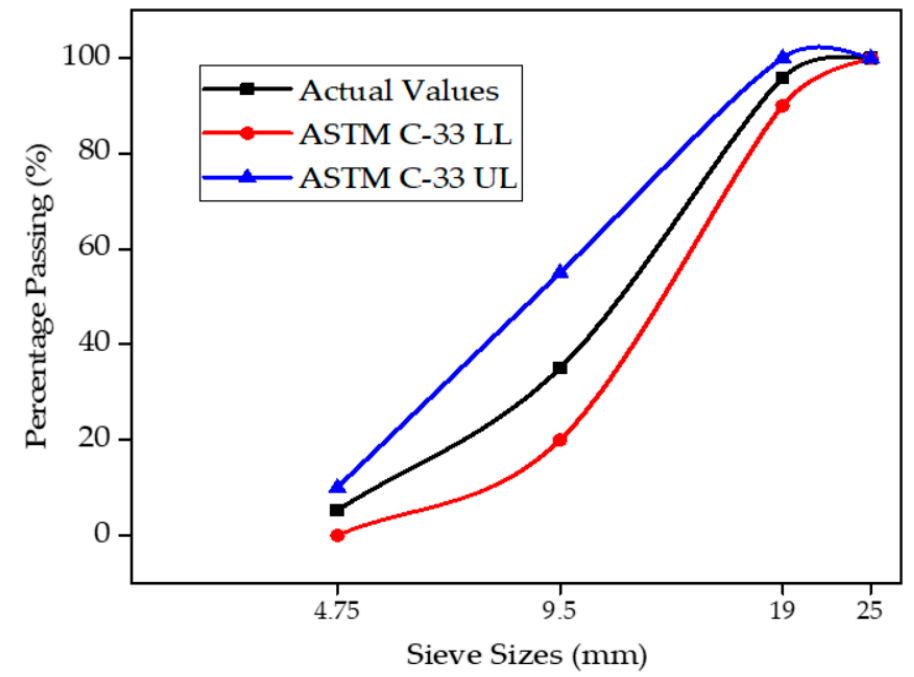

Figure 2. Particle size distribution curve of coarse aggregate in line with ASTM C-33 limits. 
Table 3. Physical properties of aggregates.

\begin{tabular}{cccc}
\hline Property & Natural Sand & Coarse Aggregate & Waste Foundry Sand \\
\hline Specific Gravity & 2.61 & 2.66 & 2.55 \\
Unit Weight $\left(\mathrm{kg} / \mathrm{m}^{3}\right)$ & 1720 & 1600 & 1555 \\
Fineness Modulus & 2.60 & - & 1.90 \\
Water Absorption $(\%)$ & 0.67 & 0.73 & 1.48 \\
\hline
\end{tabular}

Sieve analysis of WFS and natural fine aggregate (NFA) was carried out to observe the particle size distribution pattern of WFS and NFA. The sieve analysis evaluation of WFS and normal sand showed that the WFS is a finer material than NFA. The sieve analysis pattern of WFS and NFA is presented in Figure 1.

Sieve analysis of coarse aggregate was carried out to observe the particle size distribution pattern of coarse aggregate. The sieve analysis pattern of coarse aggregate is presented in Figure 2. The particle size distribution curve of actual used coarse aggregate is within the limits of ASTM C-33 limits.

Five mixtures incorporating WFS as a fractional substitution of natural sand were prepared. Normal sand was substituted by WFS by weight. The proportion of replacement ranged from $0 \%$ to $40 \%$ at the accretion of $10 \%$. The mix proportions to be used are provided in Table 4 . Three specimens were cast for each replacement level and for each day of testing as well. Similarly, three specimens were cast for each replacement level, and for each level, the temperature ranged from $300^{\circ} \mathrm{C}$ to $1000{ }^{\circ} \mathrm{C}$ at the incremental interval of $100^{\circ} \mathrm{C}$. Mix concrete without WFS was referred to as control mix and designed as per ACI-211.1-91 [42] and ACI 318-08 [43]. Mixture machine mixing was done for all the concrete mixes. Trial mixes were prepared to finalize the control or reference mix design with no addition of WFS. The target compressive strength set for control or referenced concrete mix at 28 days of age was $28 \mathrm{MPa}$.

Table 4. Mix proportions containing WFS.

\begin{tabular}{|c|c|c|c|c|c|c|}
\hline $\begin{array}{c}\text { Mix } \\
\text { Designation }\end{array}$ & $\begin{array}{c}\text { Level of } \\
\text { Replacement }\end{array}$ & $\begin{array}{l}\text { Cement } \\
\left(\mathrm{kg} / \mathrm{m}^{3}\right)\end{array}$ & $\begin{array}{c}\text { WFS } \\
\left(\mathrm{kg} / \mathrm{m}^{3}\right)\end{array}$ & $\begin{array}{l}\text { Fine Aggregate } \\
\left(\mathrm{kg} / \mathrm{m}^{3}\right)\end{array}$ & $\begin{array}{c}\text { Coarse Aggregate } \\
\left(\mathrm{kg} / \mathrm{m}^{3}\right)\end{array}$ & $\begin{array}{l}\text { Water } \\
\left(\mathrm{kg} / \mathrm{m}^{3}\right)\end{array}$ \\
\hline M-1 & $0 \%$ & 436.4 & 0 & 654.5 & 1309.1 & 187.6 \\
\hline M-2 & $10 \%$ & 436.4 & 65.4 & 589.1 & 1309.1 & 187.6 \\
\hline M-3 & $20 \%$ & 436.4 & 130.9 & 523.6 & 1309.1 & 187.6 \\
\hline M-4 & $30 \%$ & 436.4 & 196.4 & 458.2 & 1309.1 & 187.6 \\
\hline M-5 & $40 \%$ & 436.4 & 261.8 & 392.7 & 1309.1 & 187.6 \\
\hline
\end{tabular}

\section{Experimental Program}

\subsection{Fresh State Testing Procedure}

Wet/fresh state characteristics of concrete such as slump and compacting factor tests have been idenfied according to ASTM C143/143M [44] and BS 1881-103 [45] standards, respectively. For compressive and splitting tensile strengths, specimens of $150 \times 300 \mathrm{~mm}(6 \times 12$ inches $)$ concrete cylinders were casted, while prism beams of $150 \times 150 \times 500 \mathrm{~mm}(6 \times 6 \times 20$ inches $)$ were casted for finding the flexural strengths. The compressive strengths, splitting tensile strengths, and flexural strengths were performed at the age of 7 days, 28 days, 56 days, and 91 days of standard curing as per ASTM C192/C192M [46].

The mean net value of three specimens was used for all the calculations at all the ages and replacement levels. All the samples were casted at ambient temperature. Casted samples were protected with plastic sheets and left in a molding yard for $24 \mathrm{~h}$ at ambient temperature, and then demolded and kept in water for the required age of curing and test. Compressive strengths, splitting tensile, and flexural strengths tests were performed as per ASTM standards C39/C39M [47], C496/C496M [48], and C293 [49], respectively. 


\subsection{Ultrasonic Pulse Velocity (USPV) Test}

The USPV test mostly involves measuring the electronic wave velocity passing through the concrete specimen, which is used to diagnose the quality of concrete. A USPV test for concrete incorporating WFS as a partial substitute of sand was measured in the way discussed bleow.

(i) After the completion of standard curing (28 days) the samples were carried out from the curing tank and then dried at ambient temperature for seven days.

(ii) The USPV test was conducted at the seventh day after the completion of standard curing.

(iii) After that, the samples were then exposed to elevated temperatures of 300, 400, 500, 600, 700, 800, 900 , and $1000{ }^{\circ} \mathrm{C}$ for one-hour at peak temperature level.

(iv) After being exposed to elevated temperatures, the samples were placed in surrounding air/open to sky environment for 30 days.

(v) A USPV test was conducted again at the 30th day after being exposed to the surrounding air/open to sky environment.

The ultrasonic pulse velocity of the concrete samples were measured by implementing the technique specified in BS EN 12504-4:2004 [50]. USPV tests were performed with the help of Portable Ultrasonic Non-Destructive Digital Indicating Tester (PUNDIT) on the post-heated/fired and unfired/unheated concrete cylinders. The position for measuring the pulse velocity values remained the same after exposure to the specified temperature as before heating. Petroleum jelly was used to make the surface of concrete cylinders smooth. The transmitting and receiving transducers were positioned on the opposite faces of the concrete cylinders. Four readings were taken at each sample, and the average value was recorded.

\subsection{Schmidt Rebound Hammer Number (RHN) Test}

The test of the rebound hammer number (RHN) is appropriate for both the laboratory and the field. The surface smoothness influences the rebound number. An RHN test for concrete incorporating WFS as a partial substitute of sand was measured in the way discussed bleow.

(i) After the completion of standard curing (28 days), the samples were carried out from the curing tank and then dried at ambient temperature $\left(25^{\circ} \mathrm{C}\right)$ for seven days.

(ii) The RHN test was conducted on the seventh day after completion of standard curing.

(iii) After that, the samples were then exposed to elevated temperatures of 300, 400, 500, 600, 700, 800, 900 , and $1000{ }^{\circ} \mathrm{C}$ for $1 \mathrm{~h}$ at a peak temperature level.

(iv) After being exposed to elevated temperatures, the samples were placed in the surrouding air/open-sky environment for 30 days.

(v) An RHN test was conducted again at the 30th day after being exposed to the surrounding air/open-sky environment.

The rebound hammer test was performed by implementing the techniques specified in BS EN 12504-4:2004 [50], on the unfired/unheated and post-heated/fired concrete cylinders. Six readings were taken at each sample, and the average value was recorded. The rebound hammer tests belongs to the catogory of surface hardness surveys [51].

\subsection{Heating Procedure/Fire Exposure}

After completing the period of 28 days of standard curing/watering, the entirely cured samples were picked out from the curing tank and dried out at ambient temperature for seven days. The concrete specimens (cylinders of $150 \times 300 \mathrm{~mm}$ size) were fired/heated in an electric furnace for the temperature levels of $300,400,500,600,700,800,900$, and $1000{ }^{\circ} \mathrm{C}$ at a mean rate of $4.5^{\circ} \mathrm{C} / \mathrm{min}$. The level of temperature/hotness was increased in accordance with the fire curve of ISO-834-12 [52]. 
The highest/peak temperature was kept for a duration/period of one hour, and then samples were allowed to cool down slowly to room temperature overnight in the closed furnace. Once cooled, the specimens were taken out of the furnace and stored in an open air environment for 30 days. The time-temperature curve is illustrated in Figure 3. The temperature graph revealed a similar trend to those of ISO-834-12 and ASTM E119, respectively [52,53]. The samples were tested for residual compressive strength after the completion of 30 days of cooling in the surrounding air after exposure to different temperature levels ranging from 300 to $1000{ }^{\circ} \mathrm{C}$ at the increment of $100^{\circ} \mathrm{C}$. Then, the average residual strength values were recorded for all the specimens at each temperature. To study the behaviour of Foundry sand concrete exposed to elevated temperatures, three specimens were used for each of the following temperatures: $300,400,500,600,700,800,900$, and $1000{ }^{\circ} \mathrm{C}$. It is important to mention here that the elevated temperature response was noted only for specimens that were cured for 28 days.

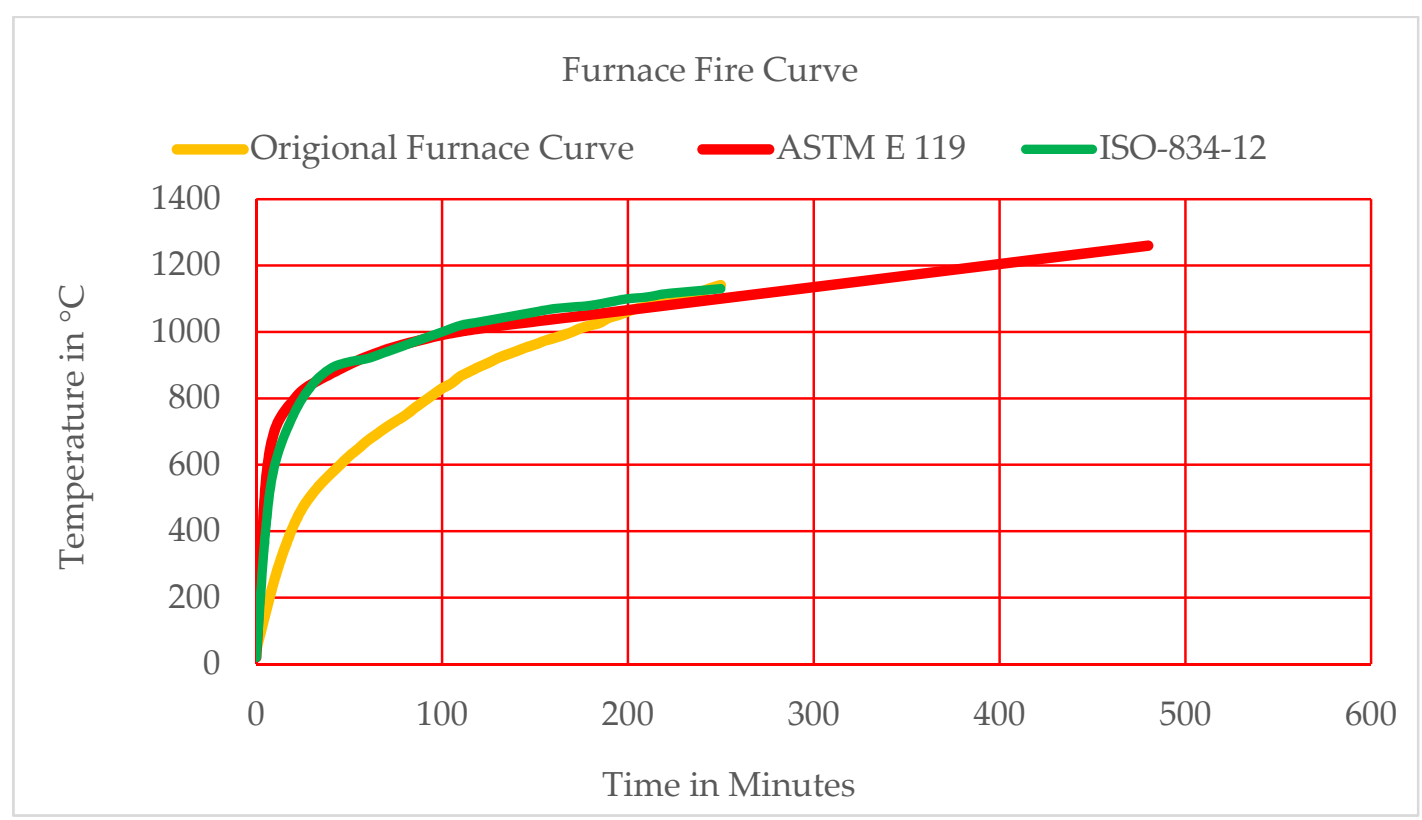

Figure 3. Used furnace temperature variation times in this present study.

\section{Results and Discussion}

\subsection{Fresh State Testing Results}

Wet concrete workability is the combination of composite properties that contains the necessities of ease in compaction, mobility, finishibility, and placeability. Slump is the indicative measurement of consistency or workability of concrete. The compacting factor is also in correspondance with the slump values. The slump value was noted to decrease with the incorporation of WFS because of the finer particles present in foundry sand. Water demand escalated with the escalating percentage substitution of foundry sand. Beyond 30\% replacement, water demand increased in order to achieve the desired workability. As observed, the slump values decreased with the increase in replacement level. This might be due to the void-filling act of the WFS, as its particles are finer than the natural sand, which contributes high unity to the mix. The mix comprised of a high level of substitution of waste foundry sand content tends to become harsh, sticky, and stiff/inflexible beyond 30\% replacement. Up to 30\%, the mix was not so harsh, as we observed in mixing and placing. At a replacement rate of $30 \%$, nearly a $15 \%$ decrease in slump value was noted. At the replacement point of $40 \%$, the decrease in slump value was boosted up to around $31 \%$. This reduction in workability is likely owing to the existence in WFS of water absorbing finer particles, i.e. clay-type fine material, ashes, and impurities, etc., which are accountable for reducing the fluidity of wet concrete and escalating the water demand. Similarly, a 
reducing trend in compacting factor $(\mathrm{CF})$ values has also been noted with the increasing WFS level. The findings of this research are in agreement with those observed by $[13,14,24,54-56]$. Table 5 shows the results of the fresh properties of all the mixtures.

Table 5. Slump and compacting factor (CF) values at different substitution levels.

\begin{tabular}{ccccc}
\hline Mix Designation & Level of Replacement & $\begin{array}{c}\text { Actual Slump } \\
\text { Achieved (mm) }\end{array}$ & $\begin{array}{c}\text { Slump Value } \\
\text { (\%age reduction) }\end{array}$ & $\begin{array}{c}\text { Compacting } \\
\text { Factor Value }\end{array}$ \\
\hline M-1 & $0 \%$ & 32 & Reference Slump & 0.85 \\
M-2 & $10 \%$ & 30 & 6.25 & 0.84 \\
M-3 & $20 \%$ & 30 & 6.25 & 0.84 \\
M-4 & $30 \%$ & 27 & 15.62 & 0.83 \\
M-5 & $40 \%$ & 22 & 31.25 & 0.81 \\
\hline
\end{tabular}

\subsection{Compressive Strength Results}

The compressive strength (CS) for all the mixtures consisting of WFS as a partial substitute of sand i.e., $0-40 \%$ at the increment of $10 \%$ was performed at the age of $7,28,56$, and 91 days. The CS increased by up to $30 \%$ substitution level in linear behavior, and at the substitution level of $40 \%$, the strength is nearly equal to the strength of the control mixture at all the ages. There is an increase in compressive strength at each replacement level, and a maximum increase in compressive strength was observed at a 30\% replacement level. At 7 days of age, the percentage increase in CS as compared to the control mixture was $2.53 \%, 4.56 \%, 7.62 \%$, and $1.45 \%$ for mixtures comprising $10 \%, 20 \%, 30 \%$, and $40 \%$, respectively. The concrete mixture containing $30 \%$ WFS at 7 days of age had a maximum compressive strength of $23.30 \mathrm{MPa}$, i.e., $7.62 \%$ higher than that of the control concrete. Concrete mixtures comprised of WFS of up to $10 \%, 20 \%, 30 \%$, and $40 \%$ at 28 days of age gained $2.67 \%, 4.72 \%, 7.82 \%$, and $1.65 \%$, respectively, higher CS than that of the control mix.

At 56 days of age, the enhancement in CS of concrete comprising of $10 \%, 20 \%, 30 \%$, and $40 \%$ WFS respectively over that of control mixture was $7.13 \%, 11.31 \%, 12.59 \%$, and $5.86 \%$, respectively. Similarly, at the level of 91 days, there were $11.18 \%, 14.78 \%, 16.65 \%$, and $9.59 \%$ increases in CS for concrete mixtures comprising of $10 \%, 20 \%, 30 \%$, and $40 \%$ WFS respectively over that of control concrete. From Figure 4 mentioned below, the variation in CS enhancement can also be easily observed. It was noted that at all ages, concrete mixture comprising of $30 \%$ WFS as a partial sand substitute exhibited a higher CS value than that of the control concrete mixture. It was also noted that the strength-increasing pattern of concrete comprising WFS as a fractional substitute of sand with the age was similar to that of control concrete.

This is may be due to the existence in WFS of more fine particles that acted as excellent packing material and eventually resulted in a denser concrete mix [57]. The void-filling of finer particles decreases the pores among the concrete component, and results in a dense matrix. A reduction in the electrical conductance of concrete has also occurred [17]. The presence of silica content would have helped in the formation of CSH gel. It is undoubtedly because of the packing behavior of the matrix particles [13-15]. The strength reduction was noted beyond 30\% replacement. This significant drop in CS with the incoporation of $40 \%$ WFS could possibly be due to an increase in the surface area of fine particles leading to a reduction of the water-cement gel in matrix; hence, the binding process of coarse and fine aggregate is not carried out correctly [17]. The findings of this research in terms of CS are in line with several others research findings [13-15,17,25-27].

The findings of distinct mixtures for compressive strength (CS) incorporating WFS at various ages are shown in Figure 4. Concrete mixtures produced with WFS could be noted as having greater CS than control concrete. The control mixture CS was around 28.1 MPa after 28 days of curing, and its value is very close to the mixture containing $40 \%$ WFS. The maximum strength was observed at a $30 \%$ replacement level, as clear from Figure 4. 


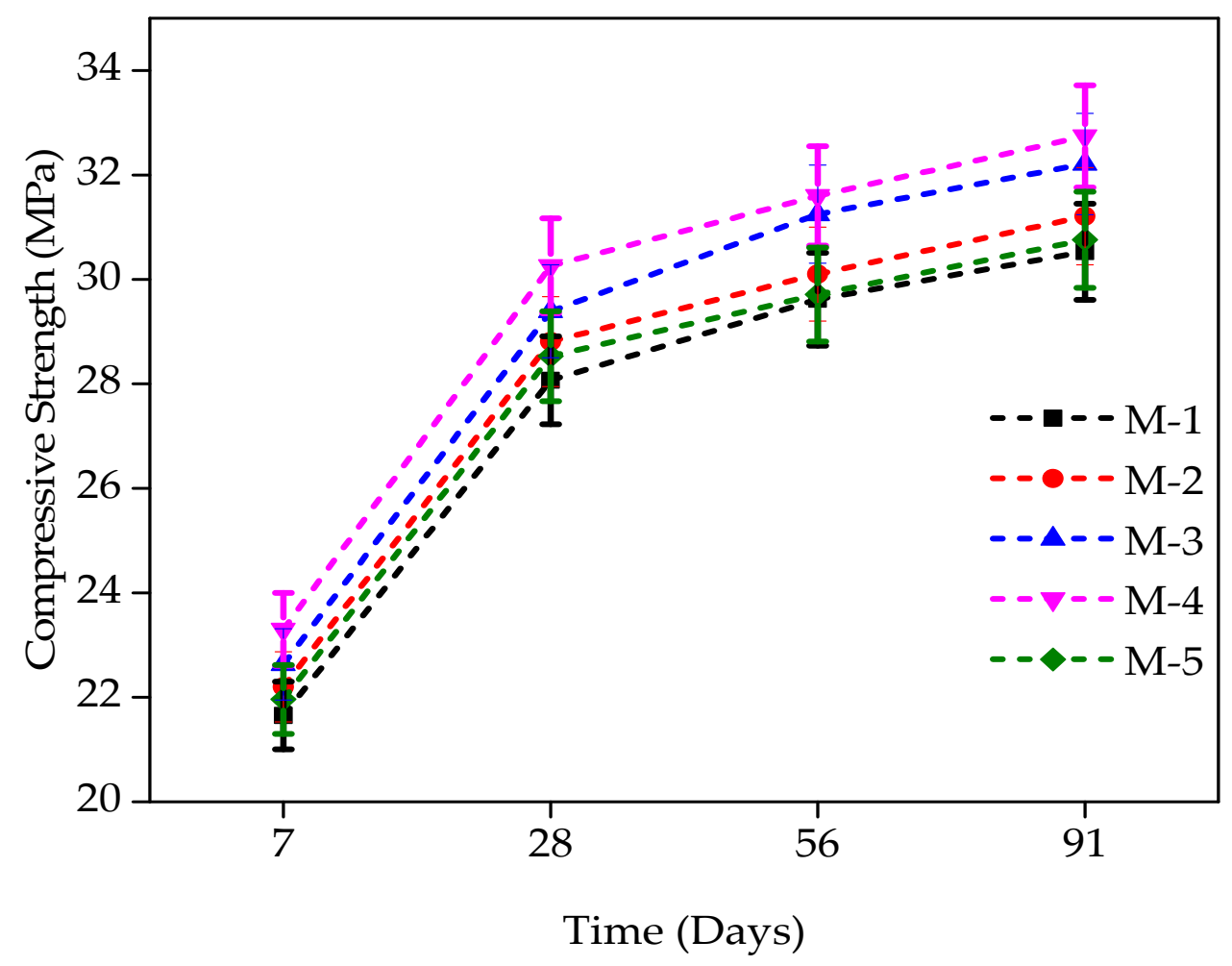

Figure 4. Compressive strength development of WFS concrete at various ages [47].

\subsection{Splitting Tensile Strength Results}

The splitting tensile strength (STS) for all the mixtures consisting of WFS as a partial substitute were performed at the age of $7,28,56$, and 91 days. The STS behavior of the control and WFS concrete mixtures are shown in Figure 5. The strength gain trend of WFS-based concrete mixtures is compatible with the trend toward compressive strength (CS). With the increased content of WFS up to a replacement level of 30\%, an increase in STS was noted. The STS of a mixture having 0\% WFS was $2.02 \mathrm{MPa}$ at 7 days of age. This strength increased by $3.34 \%, 6.89 \%, 9.25 \%$, and $1.52 \%$ for mixtures incorporating $10 \%$, $20 \%, 30 \%$, and $40 \%$ WFS, respectively. After 28 days, for concrete mixtures comprising $10 \%, 20 \%, 30 \%$, and $40 \%$ WFS, respectively, the STS was increased by $3.38 \%, 7.46 \%, 9.87 \%$, and $2.50 \%$, respectively. The strength was very analogous to that of the referenced mixture at the replacement stage of $40 \%$.

At 56 days of age, concrete mixtures comprised of $10 \%, 20 \%, 30 \%$, and $40 \%$ WFS achieved an increase of $5.48 \%, 11.17 \%, 13.14 \%$, and $4.80 \%$, respectively, over the STS of control concrete. At the age of 91 days, increments of $6.18 \%, 9.09 \%, 13.87 \%$, and $16.07 \%$ were observed for mixtures comprising $10 \%, 20 \%, 30 \%$, and $40 \%$ of WFS, respectively compared to the control concrete mixture. A maximum increase in STS for a concrete mixture containing 30\% WFS was observed. As observed, the STS of WFS concrete mixtures increased with the age and with the WFS content up to a $30 \%$ level of substitution.

The change in STS with the content of WFS was similar to that observed for CS. The results of the present study are in good agreement with the findings of [4,5,8-12]. In this current investigation, the connection among CS and STS was observed in accordance with that of conventional concrete, i.e., the proportion of STS to CS for all the mixes was noted to be lying within the range of $8-15 \%$ [58]. Most of the concrete features are directly associated with its CS. Knowing its CS, the quality of concrete can be readily assessed. The findings show that the splitting tensile performance of plain concete with a partial substitution of natural sand by mass up to a substitution point of $30 \%$ is not adversely affected. Furthermore, the findings suggest a confirmed adverse effect on STS of plain concrete with the incorporation of WFS in excess of $40 \%$. 


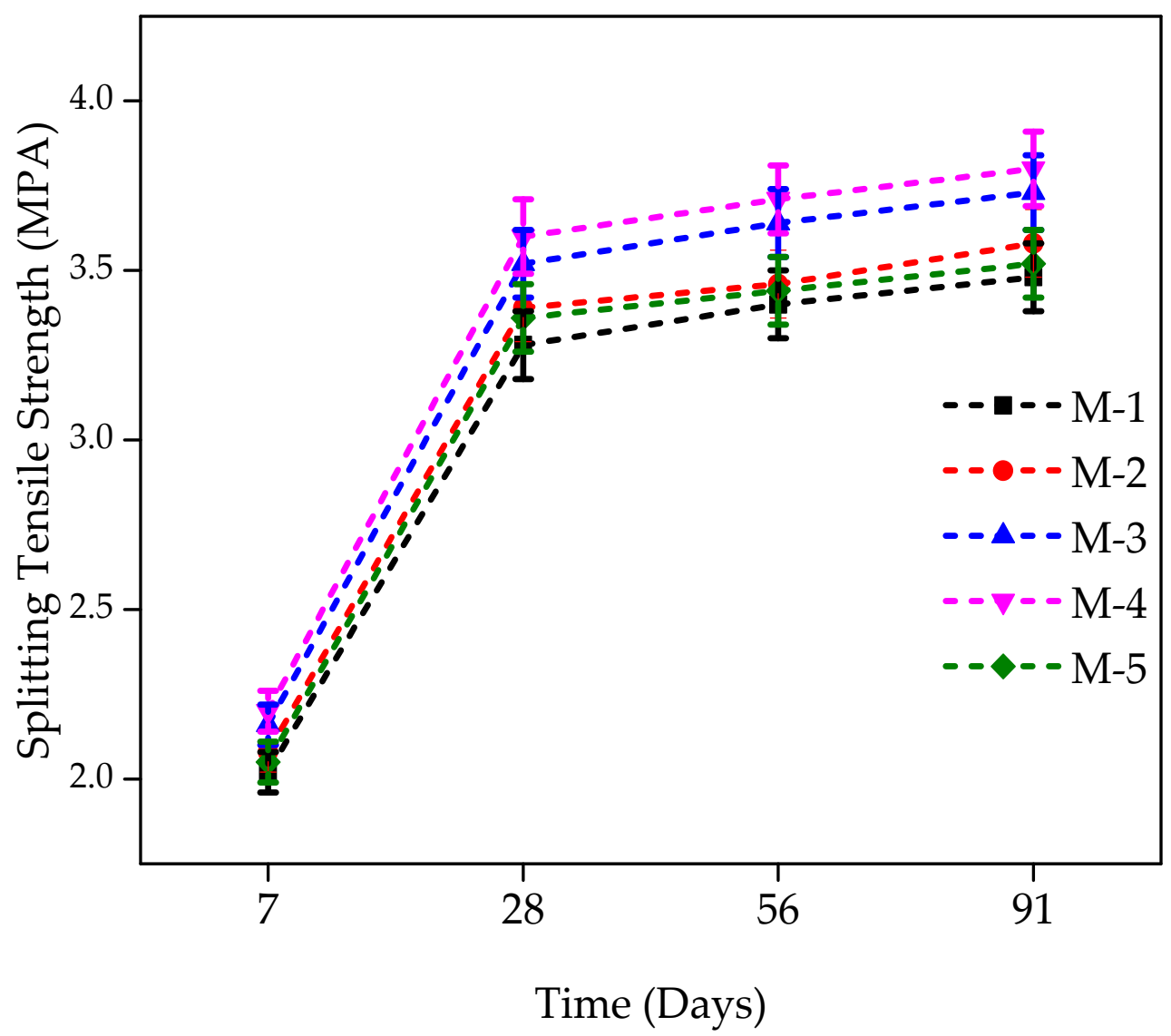

Figure 5. Splitting tensile strength development of WFS concrete at various ages [48].

The splitting tensile strength (STS) tests results of different mixtures consisting of WFS at various ages are shown in Figure 5. Concrete mixtures produced with WFS could be noted to expose greater STS than control concrete. The control mixture STS was around $3.28 \mathrm{MPa}$ after 28 days of curing, and its value is very close to the mixture containing $40 \%$ WFS. The maximum strength was observed at a $30 \%$ replacement level at all the ages, as clear from Figure 5 .

\subsection{Flexural Strength Tests Results}

Concrete tensile strength in terms of flexural strength (FS) is quite essential. The FS for concrete incorporating WFS as a partial substitute of sand was measured after the completion of 7 days, 28 days, 56 days, and 91 days of standard curing in accordance with ASTM C293 [49]. The results are shown in Figure 3. Similar to the CS and STS, with the incorporation of WFS as a partial sand substitution, the flexural strength (FS) has also been observed for the increments, and follows the same trend. At seven days of age, the FS was 5.02, 5.17, 5.37, 5.53, and 5.11 MPa, respectively for M-1, M-2, M-3, M-4, and M-5. For M-2, M-3, M-4, and M-5 mixtures, a marginal increment in FS over that of the control mixture was $2.99 \%, 6.82 \%, 10.00 \%$, and $1.78 \%$, respectively at 7 days of age. The FS of the control mixture M-1 (0\% WFS) was $6.15 \mathrm{MPa}$, at 28 days, while mixtures of $10 \%, 20 \%, 30 \%$, and $40 \%$ of WFS achieved FS of $6.34,6.65,6.78$, and $6.27 \mathrm{MPa}$, revealing a marginal increment of $3.12 \%, 8.20 \%, 10.35 \%$, and $2.01 \%$, respectively compared to the control mixture. At 56 days of age, concrete mixtures of $10 \%$, $20 \%, 30 \%$, and $40 \%$ of WFS achieved an increase of $6.59 \%, 10.79 \%, 11.64 \%$, and $4.14 \%$ respectively over the FS of control concrete. At 91 days of age, increments of $8.33 \%, 12.47 \%, 13.45 \%$, and $4.14 \%$ were observed respectively, for mixtures consisting of $10 \%, 20 \%, 30 \%$, and $40 \%$ WFS compared to the control concrete mixture. A marginal increase was observed for a substitution level of $30 \%$ at all the days of testing. A strength reduction was noted beyond a 30\% replacemnt level. The FS value of M-1 and M-5 is very similar. This finding is in line with some other research findings such as those of $[4,5,8-12]$. 
The flexural strength (FS) tests findings of different mixtures incorporating WFS at various ages are shown in Figure 6. The FS possesses the same pattern as those of the STS and CS. Concrete mixtures produced with WFS could be noted as showing greater FS than control concrete. The control mixture's FS was around $6.15 \mathrm{MPa}$ after 28 days of curing, and its value was very close to the mixture containing $40 \%$ WFS. The maximum strength was observed at the $30 \%$ replacement level at all ages, as clear from Figure 6.

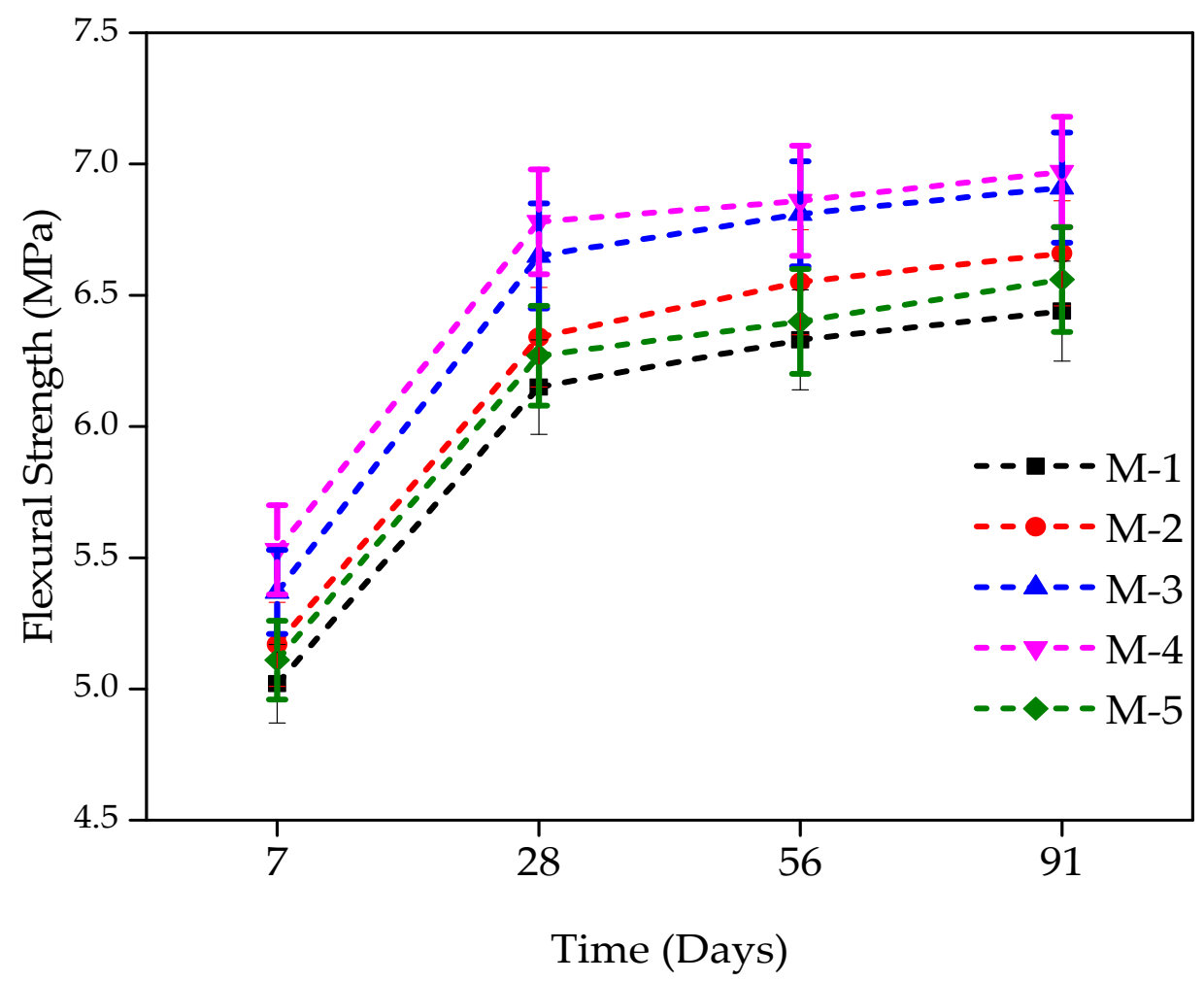

Figure 6. Flexural strength development of WFS concrete at different days [49].

\subsection{Variance in Batch Results}

This section provides information about the variation in test results at all ages. It is important to mention here that the variance in the test results of different samples is within the limits prescribed by ASTM standards. As a case study, the variance in the results of one batch i.e., M-1, is specified and given in Table 6. All the values shown in Table 6 are within the limits of the ASTM standards specified for different tests [47-49].

Table 6. Variance of results in one batch (M-1).

\begin{tabular}{|c|c|c|c|c|c|c|c|}
\hline $\begin{array}{l}\text { Testing } \\
\text { Period }\end{array}$ & $\begin{array}{c}\text { No. of } \\
\text { Samples }\end{array}$ & $\begin{array}{c}\text { Compressive } \\
\text { Strength (MPa) }\end{array}$ & $\begin{array}{l}\text { Variance } \\
(\%)\end{array}$ & $\begin{array}{l}\text { Splitting Tensile } \\
\text { Strength (MPa) }\end{array}$ & $\begin{array}{c}\text { Variance } \\
(\%)\end{array}$ & $\begin{array}{c}\text { Flexural } \\
\text { Strength (MPa) }\end{array}$ & $\begin{array}{c}\text { Variance } \\
(\%)\end{array}$ \\
\hline \multirow{2}{*}{7 Days } & Sample 1 & 20.81 & $0.00 \%$ & 1.84 & $0 \%$ & 4.89 & $0 \%$ \\
\hline & Sample 3 & 22.35 & $7.44 \%$ & 2.05 & $12 \%$ & 5.41 & $11 \%$ \\
\hline \multirow[b]{2}{*}{28 Days } & Sample 1 & 27.16 & $0.00 \%$ & 3.02 & $0 \%$ & 5.99 & $0 \%$ \\
\hline & Sample 2 & 28.09 & $3.42 \%$ & 3.36 & $11 \%$ & 6.14 & $2 \%$ \\
\hline \multirow{3}{*}{56 Days } & Sample 1 & 29.36 & $0.00 \%$ & 3.31 & $0 \%$ & 6.04 & $0 \%$ \\
\hline & Sample 2 & 29.56 & $0.68 \%$ & 3.39 & $2 \%$ & 6.37 & $5 \%$ \\
\hline & Sample 3 & 29.96 & $2.04 \%$ & 3.50 & $6 \%$ & 6.57 & $9 \%$ \\
\hline \multirow[b]{2}{*}{91 Days } & Sample 1 & 30.25 & $0.00 \%$ & 3.34 & $0 \%$ & 6.18 & $0 \%$ \\
\hline & Sample 2 & 30.57 & $1.06 \%$ & 3.44 & $3 \%$ & 6.57 & $6 \%$ \\
\hline
\end{tabular}




\subsection{Residual Compressive Strength}

The concrete cylindrical specimens have been heated to $300,400,500,600,700,800,900$, and $1000{ }^{\circ} \mathrm{C}$. The specimens were put in an open-sky environment for 30 days before assessing the compressive strength. After exposure to elevated temperatures, the concrete cylinders were then evaluated for their compressive strength. The residual compressive strength (RCS) after fire exposure was calculated as the percentage of the respective unfired/unheated specimen's compressive strength.

All the specimens were tested for RCS at ambient temperature in this experimental work after being exposed to a one-month cooling period in an open-sky environment. At the moment of heating/cooling, no superimposed compressive load was applied. Since the maximum strength reduction occurs in unstressed concrete rather than stressed concrete at higher temperatures [59], It is more favorable to evaluate the RCS unstressed condition [59-61]. It can be seen from Figures 7 and 8 that the RCS decreases mildly to a temperature level of $300{ }^{\circ} \mathrm{C}$. Beyond $300{ }^{\circ} \mathrm{C}$, it was observed that the reduction was very sharp because above $450{ }^{\circ} \mathrm{C}$, the $\mathrm{Ca}_{2} \mathrm{O}_{4} \mathrm{Si}$ starts to degrade into $\mathrm{CaO}$ and $\mathrm{SiO}_{2}$. This is a permanent decomposition that results in a higher loss of strength [62]. The RCS after 30 days of cooling in surrounding air when exposed to $300{ }^{\circ} \mathrm{C}$ was found to be $67.50 \%, 68.83 \%, 69.17 \%, 71 \%$, and $67.72 \%$ of unheated compressive strength values of $0 \%, 10 \%, 20 \%, 30 \%$, and $40 \%$ of WFS concrete mixtures, respectively. The RCS after 30 days of cooling in surrounding air when exposed to $400{ }^{\circ} \mathrm{C}$ was found to be $57.50 \%, 59.86 \%, 60.71 \%, 61.50 \%$, and $57.26 \%$ of the unheated compressive strength values for $0 \%, 10 \%, 20 \%, 30 \%$, and $40 \%$ replacement of WFS, respectively. The RCS after 30 days of cooling in surrounding air when exposed to $500{ }^{\circ} \mathrm{C}$ was found to be $49.00 \%, 49.38 \%, 50.26 \%, 51.50 \%$, and $49.30 \%$ of unheated compressive strength values for concrete mixtures consisting of $0 \%, 10 \%, 20 \%, 30 \%$, and $40 \%$ WFS, respectively. The RCS after 30 days of cooling in surrounding air when exposed to $600{ }^{\circ} \mathrm{C}$ was found to be $38.00 \%, 39.41 \%, 39.81 \%, 41.00 \%$, and $38.84 \%$ of the unheated compressive strength values for $0 \%, 10 \%, 20 \%, 30 \%$, and $40 \%$ replacement of WFS, respectively. The RCS after 30 days of cooling in surrounding air when exposed to $700{ }^{\circ} \mathrm{C}$ was found to be $31.00 \%, 32.92 \%, 34.84 \%, 35.00 \%$, and $30.87 \%$ of unheated compressive strength values for $0 \%, 10 \%, 20 \%, 30 \%$, and $40 \%$ replacement of WFS, respectively. The RCS after 30 days of cooling in surrounding air when exposed to $800{ }^{\circ} \mathrm{C}$ was found to be $26.00 \%, 27.93 \%, 29.86 \%, 31.50 \%$, and $25.89 \%$ of unheated compressive strength values for $0 \%, 10 \%, 20 \%, 30 \%$, and $40 \%$ replacement of WFS, respectively. Strength loss was observed because after the maximum exposure to air (about one month), the $\mathrm{CaO}$ absorbed wetness and changed to $\mathrm{Ca}(\mathrm{OH})_{2}$ follow-on in additional cracking and a drop in the concrete's RCS [63-65]. Maximum RCS was noted for the mixture containing $30 \%$ WFS as a fractional substitute of natural sand.

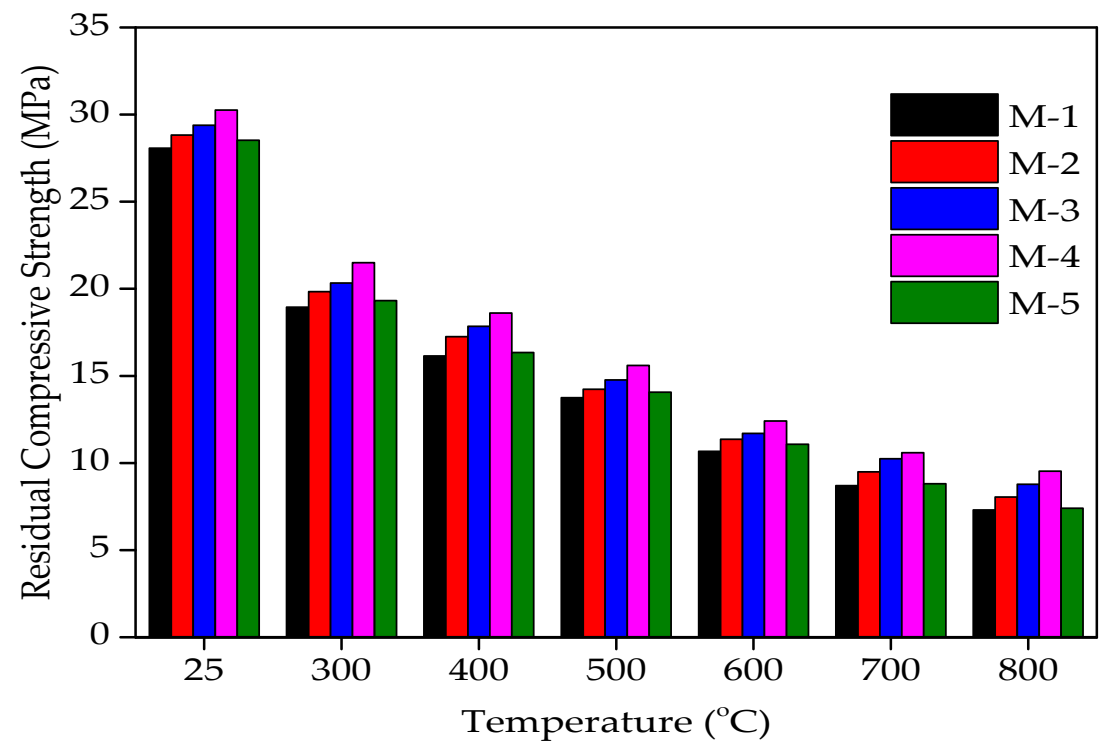

Figure 7. Residual compressive strength (RCS) of WFS concrete at various temperature levels. 


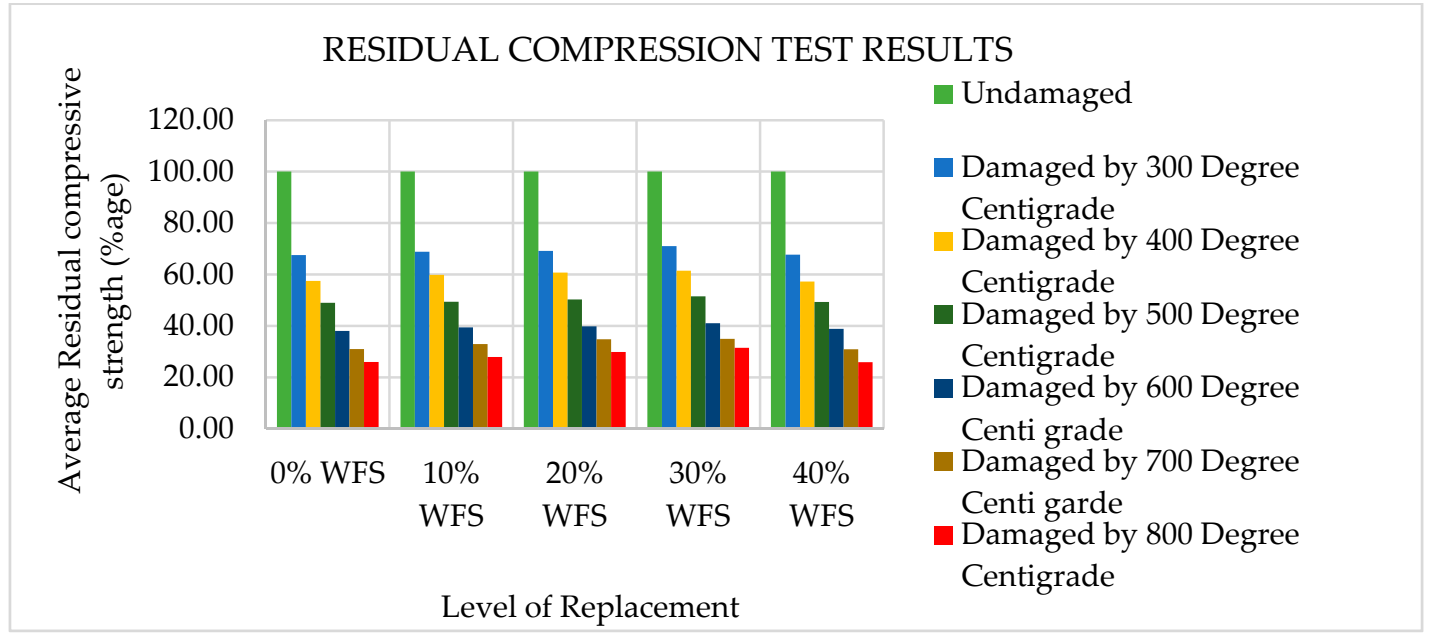

Figure 8. Variation in compressive strength after exposure to elevated temperatures.

The residual compressive strength (RCS) of various concrete mixtures incorporating WFS at various elevated temperature levels are shown in Figures 7 and 8. Strength reduction was observed from $300{ }^{\circ} \mathrm{C}$ temperature level for all of the mixtures. The maximum RCS at all of the temperature levels was noted for M-4 (30\% replacement).

\subsection{Ultrasonic Pulse Velocity Tests Results}

The USPV values of various concrete mixtures incorporating WFS as a partial substitute of sand after being exposed to various levels of elevated temperatures are shown in Figures 9 and 10. The USPV velocity reduction pattern started from the $300^{\circ} \mathrm{C}$ temperature level for all the mixtures. M- 4 had the maximum USPV values at all the temperature levels (30\% replacement).

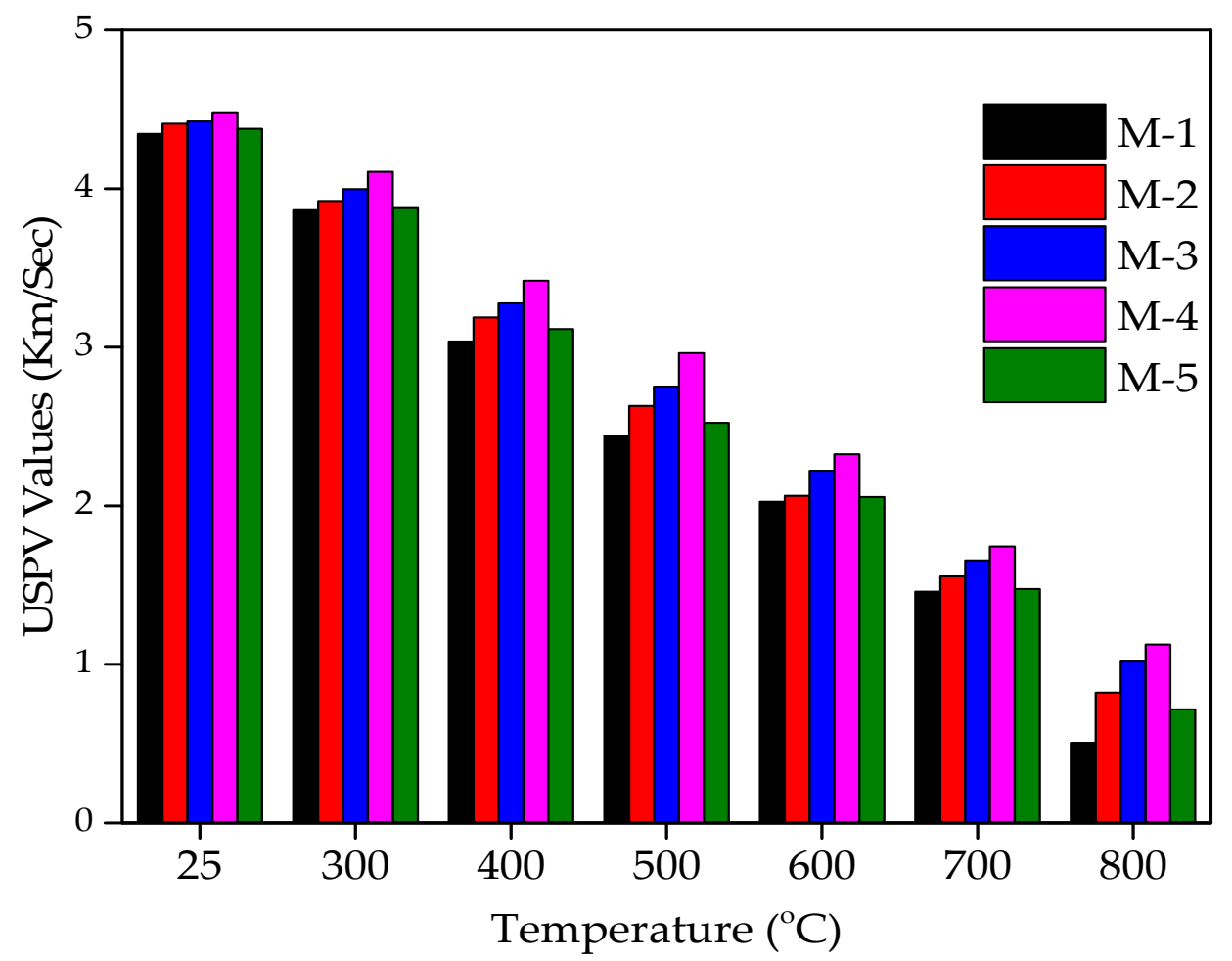

Figure 9. Ultrasonic pulse velocity (USPV) values of WFS concrete at various temperature levels. 


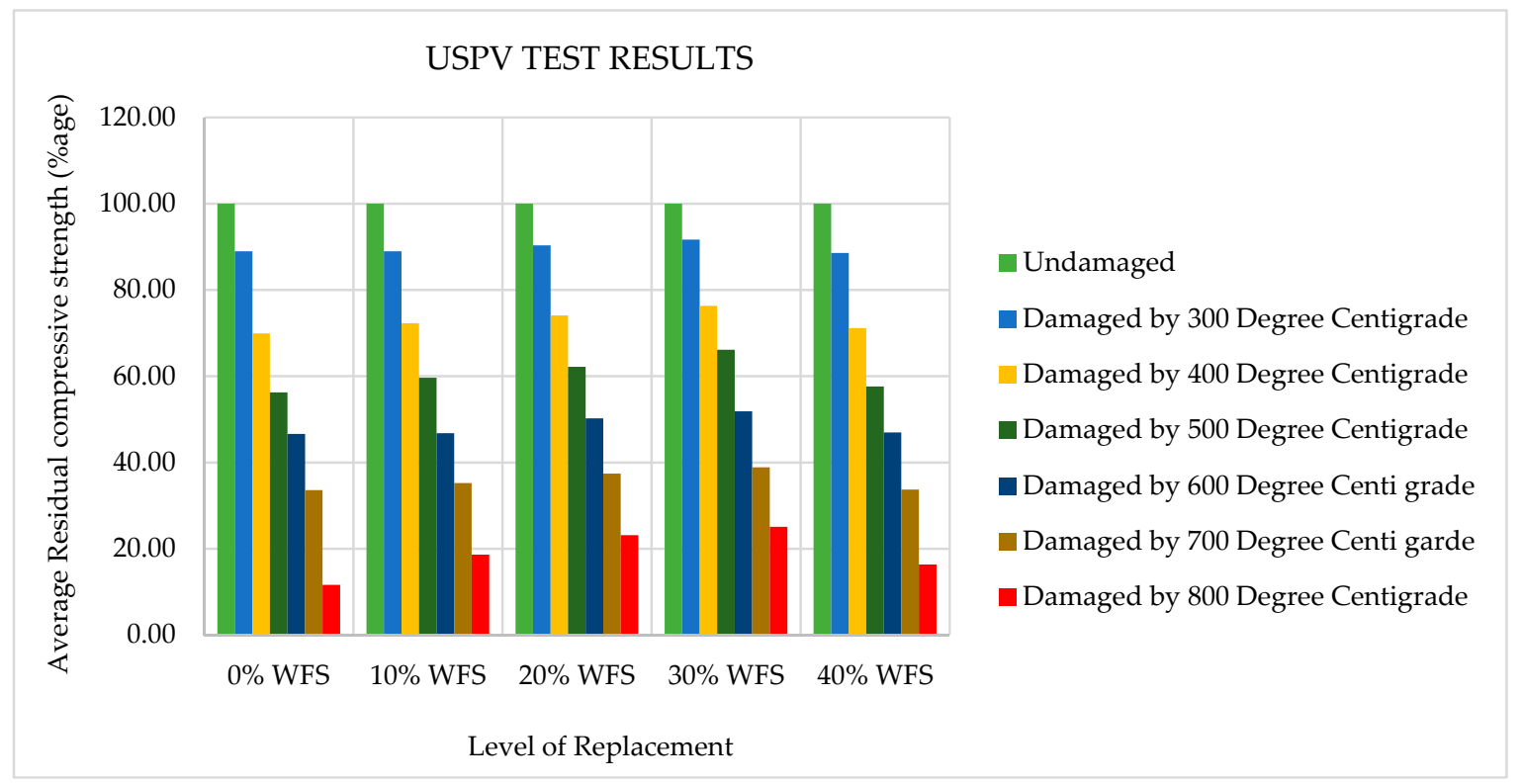

Figure 10. Variation in USPV values at elevated temperature levels.

The USPV tests results are shown in Figures 9 and 10. It can be observed from Figures 9 and 10 that the USPV values increased with the increase in WFS content in concrete mixtures up to a substitution level of 30\%. Each data point in Figures 9 and 10 represents the average of three samples and four values measured for each specimen of ultrasonic pulse velocities. The USPV test was conducted on concrete specimens consisting of $0 \%, 10 \%, 20 \%, 30 \%$, and $40 \%$ of WFS at the seventh day after 28 days of curing at ambient temperature $\left(25^{\circ} \mathrm{C}\right)$. The USPV test values were $4.345,4.410,4.425,4.482$, and $4.378 \mathrm{~km} / \mathrm{s}$ for concrete mixtures consisting of $0 \%, 10 \%, 20 \%, 30 \%$, and $40 \%$ WFS, respectively. The USPV outcomes are in good agreement with the compressive strength results. The USPV values after 30 days of cooling in surrounding air after exposure to $300{ }^{\circ} \mathrm{C}$ were found to be $3.864,3.922$, $3.997,4.107$, and $3.877 \mathrm{~km} / \mathrm{s}$ for $0 \%, 10 \%, 20 \%, 30 \%$, and $40 \%$ replacement levels of WFS, respectively. The USPV values after 30 days of cooling in surrounding air after exposure to $400{ }^{\circ} \mathrm{C}$ were found to be $3.036,3.188,3.277,3.419$, and $3.115 \mathrm{~km} / \mathrm{s}$ for concrete mixtures consists of $0 \%, 10 \%, 20 \%, 30 \%$, and $40 \%$ WFS, respectively. The USPV values after 30 days of cooling in surrounding air after exposure to $500{ }^{\circ} \mathrm{C}$ were found to be $2.443,2.630,2.752,2.962$, and $2.522 \mathrm{~km} / \mathrm{s}$ for $0 \%, 10 \%, 20 \%, 30 \%$, and $40 \%$ replacement levels of WFS, respectively. The USPV values after 30 days of cooling in surrounding air after experience to $600{ }^{\circ} \mathrm{C}$ were found to be $2.025,2.063,2.222,2.324$, and $2.055 \mathrm{~km} / \mathrm{s}$ for $0 \%, 10 \%, 20 \%$, $30 \%$, and $40 \%$ replacement levels of WFS, respectively. The USPV values after 30 days of cooling in surrounding air after exposure to $700{ }^{\circ} \mathrm{C}$ were found to be $1.458,1.554,1.655,1.742$, and $1.475 \mathrm{~km} / \mathrm{s}$ for concrete mixtures consists of $0 \%, 10 \%, 20 \%, 30 \%$, and $40 \%$ WFS, respectively. The USPV values after 30 days of cooling in surrounding air after exposure to $800{ }^{\circ} \mathrm{C}$ were found to be $0.505,0.821,1.024$, 1.125 , and $0.716 \mathrm{~km} / \mathrm{s}$ for $0 \%, 10 \%, 20 \%, 30 \%$, and $40 \%$ replacement levels of WFS, respectively. It can be seen from the very low pulse velocities of Figures 5 and 6 that the USPV of heated/fire-exposed concrete specimens decreases distinctly with the increasing level of exposure to heat/fire, and the drop in pulse values are prominently above the heated temperature level of $500{ }^{\circ} \mathrm{C}$. It is very clear that the pulse velocities are very low above the level of $600{ }^{\circ} \mathrm{C}$. This is because of the progress of wide-ranging cracks in the heated/fire-exposed concrete, which results in stopping the proceeding of the USPV, which caused low values of velocity $[66,67]$. It is obvious that the tendency of falling USPV values is similar to the tendency of falling levels of the concrete's RCS. From the figure below, variation in USPV enhancement can also be easily observed. It was noted that the concrete mixture comprising of $30 \%$ WFS as a partial sand substitute exhibited higher USPV than that of the concrete control mixture. 


\subsection{Rebound Hammer Number (RHN) Tests Results}

The RHN tests results are shown in Figures 11 and 12. With the increase in WFS content in concrete mixtures, it can noted that RHN values improved. Each data point in Figures 11 and 12 represents the average of three samples and six values measured for each specimen of rebound hammer number. The RHN test was conducted on concrete specimens consisting of $0 \%, 10 \%, 20 \%, 30 \%$, and $40 \%$ of WFS on the seventh day after 28 days of curing at ambient temperature $\left(25^{\circ} \mathrm{C}\right)$. The RHN test values are $33,33,34,35$, and 33 for concrete mixtures consists of $0 \%, 10 \%, 20 \%, 30 \%$, and $40 \%$ WFS, respectively at ambient temperature. The RHN results are in good agreement with the compressive strength and USPV results. The RHN values after 30 days of cooling in surrounding air after experience to $300{ }^{\circ} \mathrm{C}$ were found to be $28,29,30,31$, and 28 for $0 \%, 10 \%, 20 \%, 30 \%$, and $40 \%$ replacement levels of WFS, respectively. The RHN values after 30 days of cooling in surrounding air after exposure to $400{ }^{\circ} \mathrm{C}$ were found to be $25,26,27,28$, and 25 for for concrete mixtures consists of $0 \%, 10 \%, 20 \%, 30 \%$, and $40 \%$ WFS, respectively.

The RHN values after 30 days of cooling in surrounding air after exposure to $500{ }^{\circ} \mathrm{C}$ were found to be $21,22,23,24$, and 25 for $0 \%, 10 \%, 20 \%, 30 \%$, and $40 \%$ replacement levels of WFS, respectively. The RHN values after 30 days of cooling in surrounding air after experience to $600{ }^{\circ} \mathrm{C}$ were found to be $20,21,22,23$, and 21 for $0 \%, 10 \%, 20 \%, 30 \%$ and $40 \%$ replacement levels of WFS, respectively. The RHN values after 30 days of cooling in surrounding air after experience to $700{ }^{\circ} \mathrm{C}$ were found to be $16,17,18$, 20 and 16 for for concrete mixtures consists of $0 \%, 10 \%, 20 \%, 30 \%$, and $40 \%$ WFS, respectively. The RHN values after 30 days of cooling in surrounding air after exposure to $800{ }^{\circ} \mathrm{C}$ were found to be 14 , $15,16,18$ and 14 for $0 \%, 10 \%, 20 \%, 30 \%$, and $40 \%$ replacement levels of WFS, respectively. It can be seen from the very low rebound hammer number of Figures 7 and 8 that the RHN of heated/fire-exposed concrete specimens decreases distinctly with the increasing level of exposure to heat/fire, and the drop in $\mathrm{RHN}$ values is prominently above the level of heated temperatures of $500{ }^{\circ} \mathrm{C}$. It is very clear that RHN values are very low above the level of $600^{\circ} \mathrm{C}$. It is obvious that the tendency of falling in RHN values is similar to the tendency for the RCS of concrete and USPV values to drop. It was observed that concrete mixture consisting of $30 \%$ WFS as a partial sand replacement showed higher RHN than control concrete mixture.

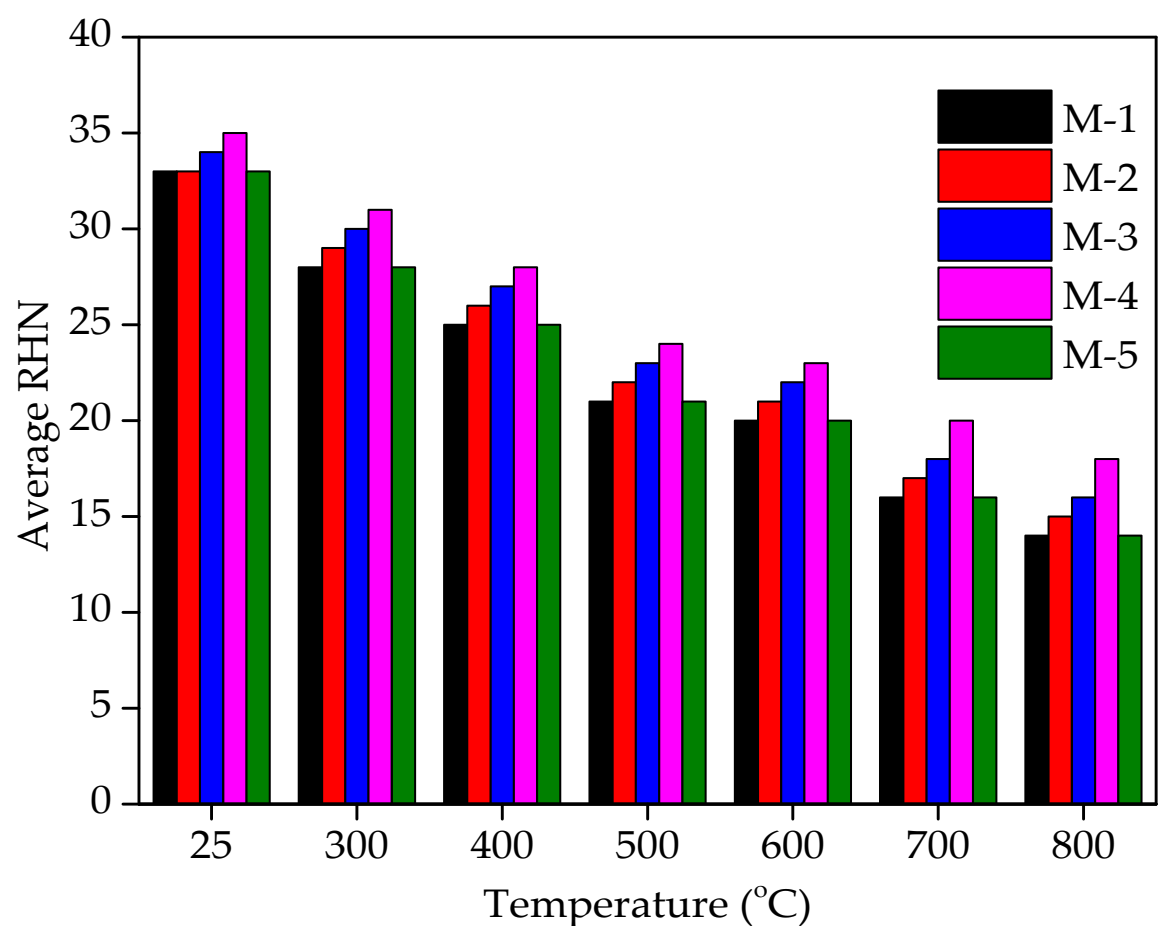

Figure 11. RHN values of WFS concrete at different temperature levels. 


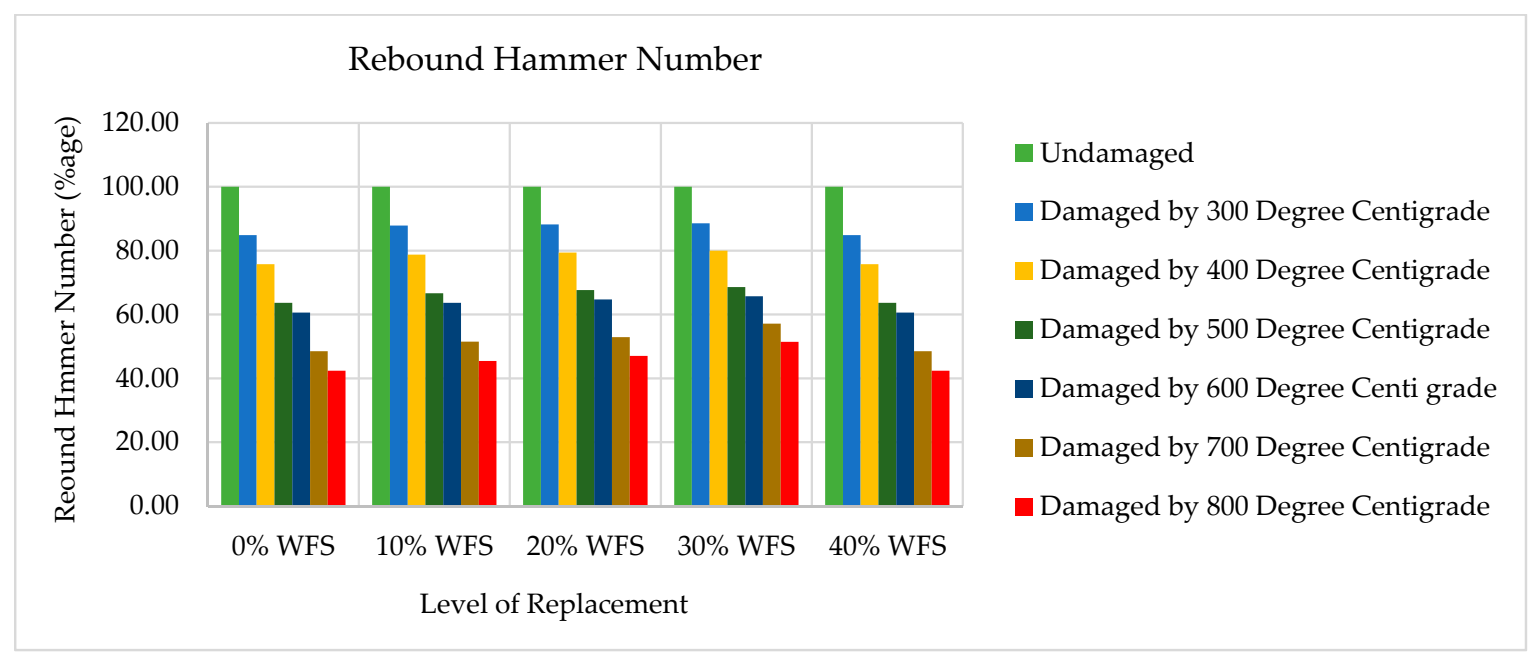

Figure 12. Variation in rebound hammer number (RHN) with elevated temperatures.

\subsection{Relationship between the Compressive Strength and USPV}

Figure 13 displays the connection between compressive strength and the USPV test. As the value of $R^{2}$ exceeds 0.94 , an association in the form of $\left\{0.756 \times(\mathrm{USPV} \text { value })^{2.458}, \mathrm{R}^{2}=0.97\right\}$ seems to be fit the data connection. A higher value of coefficient of determination shows that the CS has a strong connection with the USPV test. In general, an increase in the compressive strength with the inclusion of WFS increases the value of the USPV test, which is the indication of the concrete's quality and homogeneity.

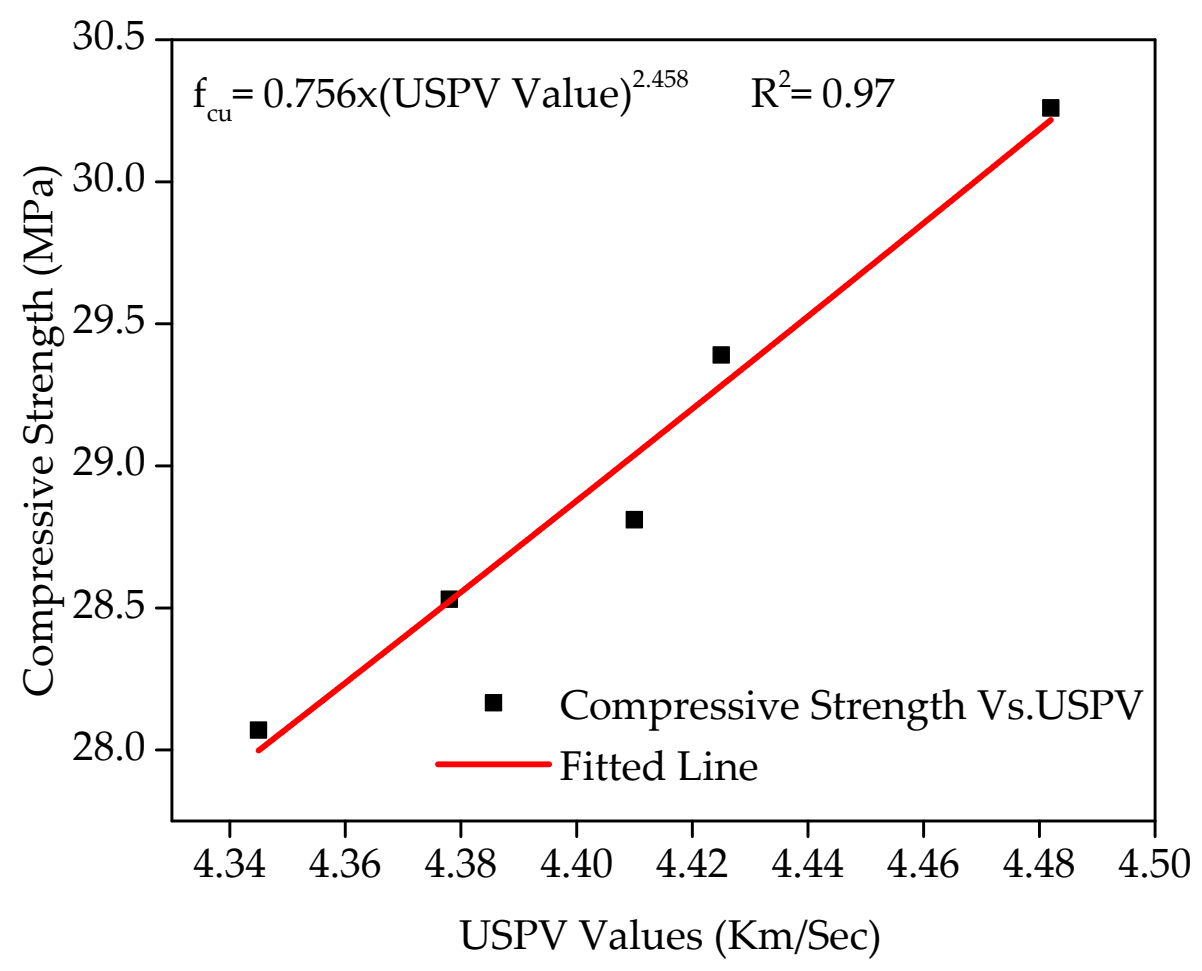

Figure 13. Relationship of compressive strength versus USPV.

\subsection{Relationship between the Compressive under Different Temperature and WFS Content}

Figure 14 displays the connection between compressive strength under various levels of temperature and WFS content. Compressive strengths of various mixtures incorporating WFS 
as a partial substitute of sand at ambient temperature and elevated temperatures have been shown in Figure 14. Figure 14 demonstrates very obviously that M-4 has a peak value of compressive strength (CS) at ambient temperature and residual compressive strength (RCS) after exposure to elevated temperatures. It can be seen that the RCS decreases insignificantly to a temperature level of $300^{\circ} \mathrm{C}$. Beyond $300{ }^{\circ} \mathrm{C}$, it was observed that the reduction was very sharp, because above $450{ }^{\circ} \mathrm{C}$, the $\mathrm{Ca}_{2} \mathrm{O}_{4} \mathrm{Si}$ starts to degrade into $\mathrm{CaO}$ and $\mathrm{SiO}_{2}$. This is a permanent decomposition that results in a higher loss of strength [62]. Maximum strength loss was observed because upon the maximum exposure to air (at about one month), the $\mathrm{CaO}$ absorbed wetness and changed to $\mathrm{Ca}(\mathrm{OH})_{2}$ follow-on in additional cracking and a drop in the concrete's RCS [63-65].

As the value of $\mathrm{R}^{2}$ exceeds 0.94 , a polynomial association in different forms seems to be the best data connection with the various values of temperature and WFS contents. A coefficient of determination of $\mathrm{R}^{2}=0.99$ shows a strong data connection. A higher coefficient of determination value shows that compressive strength has a strong connection with various WFS content and temperature levels. Equations for each level of replacement and temperature are given below in Equations (1)-(5).

$$
\begin{array}{ccc}
\mathrm{f}_{\mathrm{cuM}-1}=29.04-0.0374 \times T+1.2448 \times 10^{-5} \times T^{2} & 25^{\circ} \mathrm{C} \leq \mathrm{T} \leq 800^{\circ} \mathrm{C} ; & \mathrm{R}^{2}=0.99 \\
\mathrm{f}_{\mathrm{cuM}-2}=29.84-0.0372 \times T+1.988 \times 10^{-5} \times T^{2} & 25^{\circ} \mathrm{C} \leq \mathrm{T} \leq 800^{\circ} \mathrm{C} ; & \mathrm{R}^{2}=0.99 \\
\mathrm{f}_{\mathrm{cuM}-3}=30.44-0.0379 \times T+1.3403 \times 10^{-5} \times T^{2} & 25^{\circ} \mathrm{C} \leq T \leq 800^{\circ} \mathrm{C} ; & \mathrm{R}^{2}=0.99 \\
\mathrm{f}_{\mathrm{cuM}-4}=31.38-0.0377 \times T+1.2222 \times 10^{-5} \times T^{2} & 25^{\circ} \mathrm{C} \leq \mathrm{T} \leq 800^{\circ} \mathrm{C} ; & \mathrm{R}^{2}=0.99 \\
\mathrm{f}_{\mathrm{cuM}-5}=29.491-0.0376 \times T+1.2148 \times 10^{-5} \times T^{2} & 25^{\circ} \mathrm{C} \leq \mathrm{T} \leq 800^{\circ} \mathrm{C} ; & \mathrm{R}^{2}=0.99
\end{array}
$$

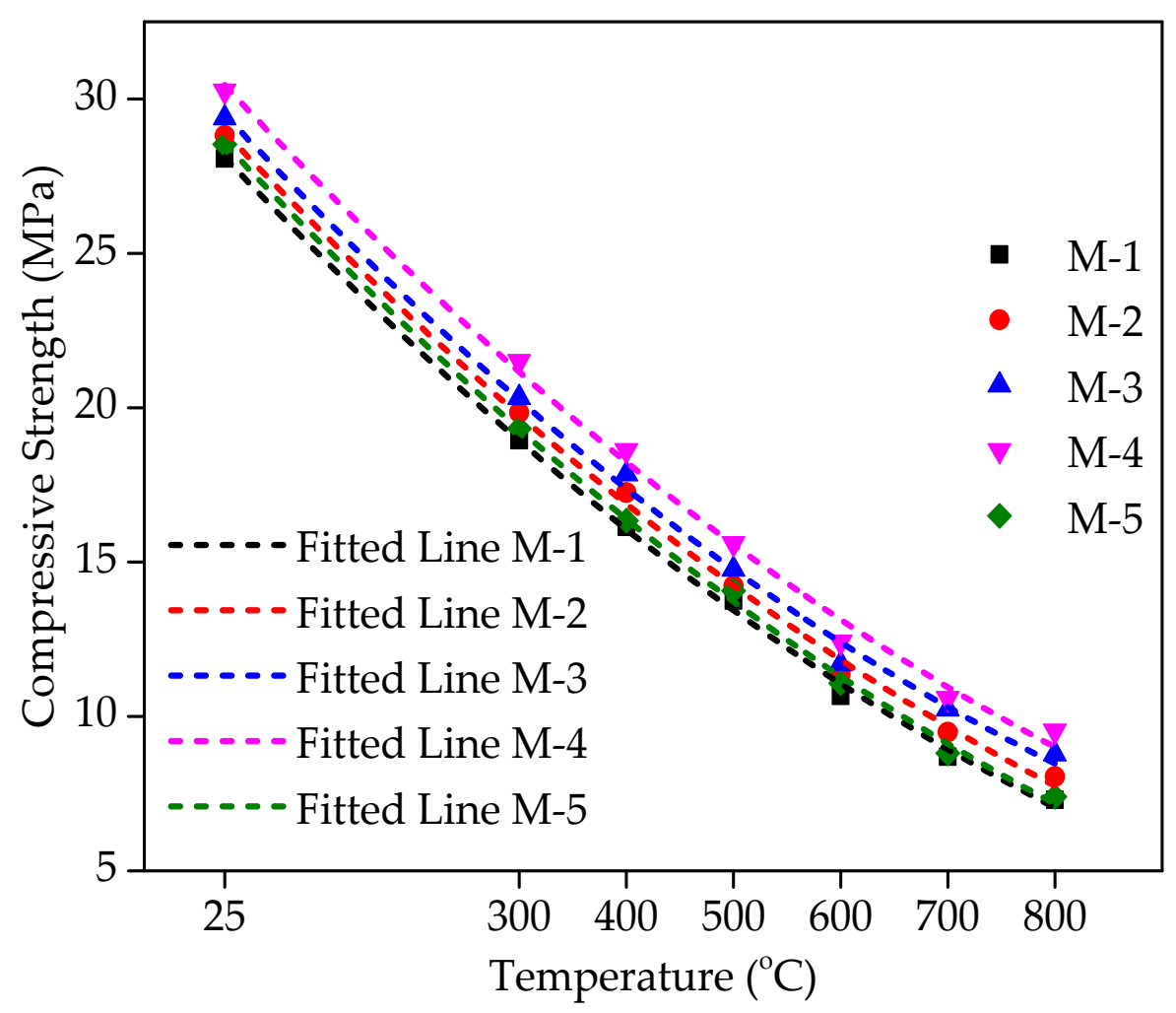

Figure 14. Relationship between the compressive under different temperatures and WFS content.

\subsection{Relationship between the RHN under different Temperatures and WFS content}

Figure 15 displays the connection between the RHN test under various levels of temperature and WFS content. The RHN test of various mixtures incorporating WFS as a partial substitute 
of sand at ambient temperature and elevated temperatures is shown in Figure 15. The pattern of increasing/decreasing RHN values and compressive strength at varying temperatures and WFS content is very evident. At ambient temperature and after exposure to higher temperatures, mixture $\mathrm{M}-4$ has a peak value of RHN at all the temperature levels. It is also noticeable that the RHN values are reduced with the increasing temperature levels, which indicates that the concrete quality is structurally influenced by higher temperatures. The RHN values for $\mathrm{M}-1$ and $\mathrm{M}-5$ concrete mixtures are very similar to each other at all the levels of elevated temperatures.

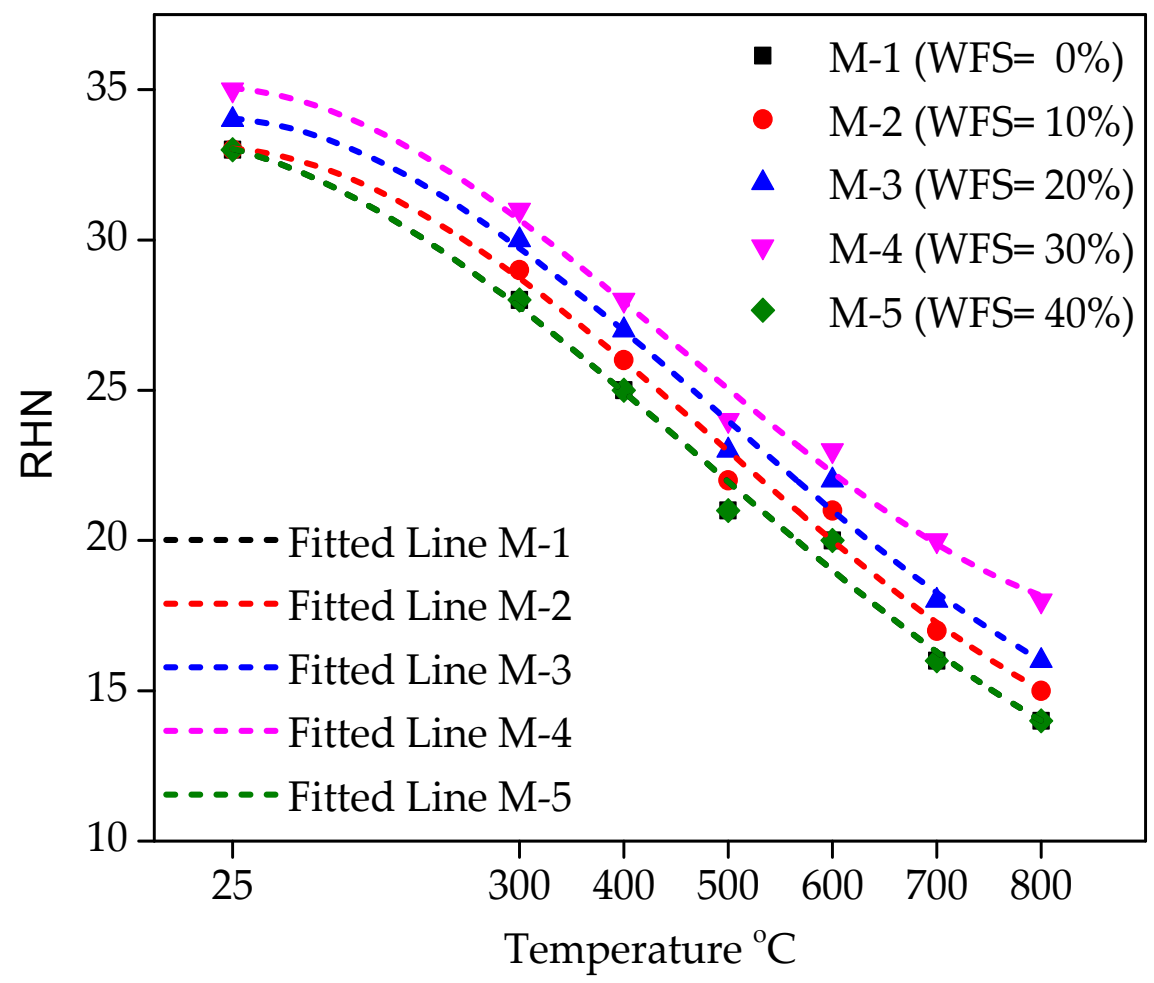

Figure 15. Relationship between the RHN under different temperature levels and WFS content.

It can be seen that the RHN decreases inconsequentially to a temperature level of $300^{\circ} \mathrm{C}$. Beyond $300^{\circ} \mathrm{C}$, it was observed that the reduction was very sharp because above $450{ }^{\circ} \mathrm{C}$, there was a breakage of $\mathrm{CSH}$ and some volumetric conversions within the structure of concrete. In addition, crakes and void generation occurs due to elevated temperature damage in the concrete matrix, which leads to a decrease in RHN values.

As the value of $R^{2}$ exceeds 0.94 , a polynomial association in different forms seems to be the best data connection with the various values of temperature and WFS contents. A coefficient of determination of $\mathrm{R}^{2}=0.99$ shows a strong data connection. A higher value of coefficient of determination shows that the RHN value has a strong connection with various WFS content and temperature levels. Equations for each level of replacement and temperature are given below (Equations (6)-(10)).

$$
\begin{gathered}
\operatorname{RHN}_{M-1}=33.232-(0.00679 \times T)-4.815 \times 10^{-5} \times(T)^{2}+3.326 \times 10^{-8}(T)^{3} \\
25^{\circ} \mathrm{C} \leq T \leq 800^{\circ} \mathrm{C} ; \mathrm{R}^{2}=0.99 \\
\operatorname{RHN}_{M-2}=33.070-\left(1.981 \times 10^{-4} \times T\right)-6.1269 \times 10^{-5} \times(T)^{2}+4.103 \times 10^{-8}(T)^{3} \\
25^{\circ} \mathrm{C} \leq T \leq 800^{\circ} \mathrm{C} ; \mathrm{R}^{2}=0.99 \\
\operatorname{RHN}_{M-3}=34.070-\left(1.981 \times 10^{-4} \times T\right)-6.1269 \times 10^{-5} \times(T)^{2}+4.103 \times 10^{-8}(T)^{3} \\
25^{\circ} \mathrm{C} \leq T \leq 800^{\circ} \mathrm{C} ; \mathrm{R}^{2}=0.99
\end{gathered}
$$




$$
\begin{aligned}
& \operatorname{RHN}_{M-4}=35.082-\left(2.895 \times 10^{-4} \times T\right)-6.398 \times 10^{-5} \times(T)^{2}+4.648 \times 10^{-8}(T)^{3} \\
& 25^{\circ} \mathrm{C} \leq \mathrm{T} \leq 800{ }^{\circ} \mathrm{C} ; \mathrm{R}^{2}=0.99 \\
& \operatorname{RHN}_{M-5}=33.232-(0.00679 \times T)-4.815 \times 10^{-5} \times(T)^{2}+3.326 \times 10^{-8}(T)^{3} \\
& 25^{\circ} \mathrm{C} \leq \mathrm{T} \leq 800^{\circ} \mathrm{C} ; \mathrm{R}^{2}=0.99
\end{aligned}
$$

\subsection{Spalling and Cracking Behavior of Foundry Sand Concrete}

Concrete spalling is a major parameter when concrete is to be exposed to elevated temperatures. Due to the significant loss of concrete strength at elevated temperatures, explosive spalling can cause a complete or abrupt failure. The temperature range is in between $300-650{ }^{\circ} \mathrm{C}$. Many factors were identified as affecting explosive spalling. These factors including the age, moisture content, type of gravel and sand used, curing method, and rate of heating. Low heating rates reduced the risk of spalling.

It is considered that pore pressure stresses play a major contribution in explosive spalling. Due to low tensile strength, chances of explosive spalling could be more in normal strength concrete [31]. In this present study, explosive spalling was observed at $650{ }^{\circ} \mathrm{C}$ and $730{ }^{\circ} \mathrm{C}$ for concrete mixtures containing $0 \%$ waste foundry sand and $10 \%$ waste foundry sand, respectively. No explosive spalling was observed for other concrete mixtures. Maximum surface spalling was observed at $900{ }^{\circ} \mathrm{C}$ and $1000^{\circ} \mathrm{C}$, along with extensive cracks, and the specimens were not able even to perform a single test. No indication of any observable cracks was found in the concrete cylinders subjected to $300{ }^{\circ} \mathrm{C}$ to $500{ }^{\circ} \mathrm{C}$. Although minor cracks were observed when concrete was subjected to $600{ }^{\circ} \mathrm{C}$. At $700{ }^{\circ} \mathrm{C}$, significant observable cracks were seen on the surface of all specimens.

\section{Conclusions}

In this study, concrete mixtures were prepared by the inclusion of WFS as a partial replacement of natural/regular sand, and then its effect was investigated on the fresh properties i.e., slump and compacting factor tests and strength properties i.e., compressive strength, splitting tensile strength, and flexural strength at the age of $7,28,56$, and 91 days. The effect of inclusion of waste foundry sand as a partial replacement of sand was also investigated in terms of the effect of elevated temperatures ranging from 300 to $800{ }^{\circ} \mathrm{C}$ at the increment of $100{ }^{\circ} \mathrm{C}$ on the compressive strength of foundry sand concrete. The USPV and rebound hammer tests were performed at the age of 28 days before exposure to elevated temperatures and on the 30th day after being exposed to elevated temperatures. The spalling phenomenon in foundry sand concrete and the control samples was carefully observed in this investigation. The findings are summarized as follows.

1. The fresh properties for all replacements were observed to be almost similar with the control mixture up to a $30 \%$ replacement level. The compacting factor values and slump values were decreased with the inclusion of waste foundry sand. Up to $30 \%$, no severe effect on the slump and compacting factor tests results were observed.

2. The strength properties i.e., compressive strengths, splitting tensile strengths, and flexural strengths values of foundry sand concrete mixtures at all ages were found to be higher than those of the control mixtures. The maximum values for strength properties were observed at a 30\% replacement level. The substitutional level of normal sand with WFS was found to be optimum at $30 \%$, and should not exceed $40 \%$. The inclusion of waste foundry sand increases the rebound number and USPV values, which is the indication of the quality, homogeneity, and impermeableness of foundry sand concrete.

3. The residual compressive strength of concrete decreases with increasing temperature. Air curing results in a further reduction of residual compressive strength. The residual compressive strength of the concrete containing waste foundry sand as a partial replacement of natural sand on the 30th day of air/open-sky cooling at ambient temperature after exposure to 300, 400, 500, 600, 700 and $800{ }^{\circ} \mathrm{C}$ was reduced in the range of $29.00 \%$ to $32.5 \%, 38.5 \%$ to $42.5 \%, 48.5 \%$ to $51.00 \%, 59.00 \%$ 
to $62.00 \%, 65.00 \%$ to $69.00 \%$, and $68.5 \%$ to $74 \%$ of unheated compressive strength values for $0 \%$ to $40 \%$ replacement of WFS, respectively.

4. The pattern of increase in USPV, rebound hammer, compressive strengths tests at ambient temperature before exposure to elevated temperatures, and the pattern of reduction in USPV, rebound hammer, and residual compressive strength test of foundry sand concrete was found to be similar with the increasing temperature.

5. The maximum value for all the tests was observed before and after exposure to elevated temperatures for a $30 \%$ replacement level of waste foundry sand.

Based on the above findings, it can be concluded that waste foundry is a suitable candidate for the partial replacement of natural sand up to $30 \%$ in making concrete.

Author Contributions: H.B. and M.Y. conceived and designed the experiments; H.B. performed the experiments; H.B. and M.Y. analyzed the data; M.Y., M.A., R.A., H.A., F.A., contributed reagents/materials/analysis tools; H.B., M.A., and S.K.U.R. wrote and review the paper respectively.

Funding: This research received no external funding.

Acknowledgments: The authors acknowledge the technical support of Muhammad Yaqub, Ataullah Shah and Anwar Khitab. The authors are thankful to ORIC of City University, Peshawar for their support in this research. The authors are also thankful to the technical staff in the Engineering Material \& Concrete laboratory at City University, Peshawar, Pakistan especially Rizwan Ullah and Muhammad Arshad whose contribution in the experimental work is really appreciated.

Conflicts of Interest: The authors declare no conflict of interest.

\section{References}

1. Mehta, P.K.; Monteiro, P.J. CONCRETE Microstructure, Properties and Materials; McGraw-Hill Education: New York, NY, USA, 2017.

2. Barcelo, L.; Kline, J.; Walenta, G.; Gartner, E. Cement and carbon emissions. Mater. Struct. 2014, 47, $1055-1065$. [CrossRef]

3. Javed, M.F.; Sulong, N.H.R.; Memon, S.A.; Rehman, S.K.; Khan, N.B. Experimental and numerical study of flexural behavior of novel oil palm concrete filled steel tube exposed to elevated temperature. J. Clean. Prod. 2018, 205, 95-114. [CrossRef]

4. Rehman, S.; Ibrahim, Z.; Memon, S.; Javed, M.; Khushnood, R. A sustainable graphene based cement composite. Sustainability 2017, 9, 1229. [CrossRef]

5. Rehman, S.K.U.; Ibrahim, Z.; Memon, S.A.; Aunkor, M.T.H.; Javed, M.F.; Mehmood, K.; Shah, S.M.A. Influence of Graphene Nanosheets on Rheology, Microstructure, Strength Development and Self-Sensing Properties of Cement Based Composites. Sustainability 2018, 10, 822. [CrossRef]

6. Siddique, R. Utilization of industrial by-products in concrete. Procedia Eng. 2014, 95, 335-347. [CrossRef]

7. Winkler, E.; Bol'shakov, A. Characterization of foundry sand waste. In Chelsea Center for Recycling and Economic Development; University of Massachusetts: Chelsea, MA, USA, 2000.

8. Çevik, S.; Mutuk, T.; Oktay, B.M.; Demirbaş, A.K. Mechanical and microstructural characterization of cement mortars prepared by waste foundry sand (WFS). J. Aust. Ceram. Soc. 2017, 53, 829-837. [CrossRef]

9. Malik, R.A.; Bajaj, E.M. Experimentally Study on the Use of Foundary Sand in the Rigid Pavement. Int. J. Latest Res. Eng. Comput. (IJLREC) 2017, 5, 78-84.

10. Javed, S. Use of Waste Foundry Sand in Highway Construction; Indiana Department of Transportation and Purdue University: West Lafayette, IN, USA, 1994.

11. Siddique, R.; Noumowe, A. Utilization of spent foundry sand in controlled low-strength materials and concrete. Resour. Conserv. Recycl. 2008, 53, 27-35. [CrossRef]

12. Bakis, R.; Koyuncu, H.; Demirbas, A. An investigation of waste foundry sand in asphalt concrete mixtures. Waste Manag. Res. 2006, 24, 269-274. [CrossRef]

13. Siddique, R.; Gupta, R.; Kaur, I. Effect of spent foundry sand as partial replacement of fine aggregate on the properties of concrete. In Proceedings of the 22nd International Conference on Solid Waste Technology and Management, Philadelphia, PA, USA, 18-21 March 2011. 
14. Siddique, R.; De Schutter, G.; Noumowe, A. Effect of used-foundry sand on the mechanical properties of concrete. Constr. Build. Mater. 2009, 23, 976-980. [CrossRef]

15. Siddique, R.; Aggarwal, Y.; Aggarwal, P.; Kadri, E.H.; Bennacer, R. Strength, durability, and micro-structural properties of concrete made with used-foundry sand (UFS). Constr. Build. Mater. 2011, 25, 1916-1925. [CrossRef]

16. Siddique, R.; Singh, G.; Belarbi, R.; Ait-Mokhtar, K. Comparative investigation on the influence of spent foundry sand as partial replacement of fine aggregates on the properties of two grades of concrete. Constr. Build. Mater. 2015, 83, 216-222. [CrossRef]

17. Singh, G.; Siddique, R. Effect of waste foundry sand (WFS) as partial replacement of sand on the strength, ultrasonic pulse velocity and permeability of concrete. Constr. Build. Mater. 2012, 26, 416-422. [CrossRef]

18. Singh, G.; Siddique, R. Abrasion resistance and strength properties of concrete containing waste foundry sand (WFS). Constr. Build. Mater. 2012, 28, 421-426. [CrossRef]

19. Dash, M.K.; Patro, S.K.; Rath, A.K. Sustainable use of industrial-waste as partial replacement of fine aggregate for preparation of concrete-A review. Int. J. Sustain. Built Environ. 2016, 5, 484-516. [CrossRef]

20. Khatib, J.; Baig, S.; Bougara, A.; Booth, C. Foundry sand utilisation in concrete production. In Proceedings of the Second International Conference on Sustainable Construction Materials and Technologies, Ancona, Italy, 28-30 June 2010.

21. Salokhe, E.P.; Desai, D. Application of foundry waste sand in manufacture of concrete. IOSRJMCE ISSN 2014, 5, 43-48.

22. Siddique, R.; Sandhu, R.K. Properties of Self-Compacting Concrete Incorporating Waste Foundry Sand. Leonardo J. Sci. 2013, 23, 105-124.

23. Pathariya Saraswati, C.; Rana Jaykrushna, K.; Shah Palas, A.; Mehta Jay, G. Application of Waste Foundry Sand for Evolution of Low-Cost Concrete. Int. J. Eng. Trends Technol. (IJETT) 2013, 4, 4281-4286.

24. Etxeberria, M.; Pacheco, C.; Meneses, J.; Berridi, I. Properties of concrete using metallurgical industrial by-products as aggregates. Constr. Build. Mater. 2010, 24, 1594-1600. [CrossRef]

25. Bhimani, D.R.; Pitroda, J.K.; Bhavsar, J.J. Effect of Used Foundry Sandand Pozzocrete Partial Replacement with Fine Aggregate and Cement in Concrete. Int. J. Innov. Technol. Explor. Eng. 2013, 5, 2278-3075.

26. Torres, A.; Bartlett, L.; Pilgrim, C. Effect of foundry waste on the mechanical properties of Portland Cement Concrete. Constr. Build. Mater. 2017, 135, 674-681. [CrossRef]

27. Raval, A.D.; Pamnani, A.; Kachwala, A.I. Foundry Sand: Utilisation as a Partial Replacement of Fine Aggregate for Establishing Sustainable Concrete. Inter. J. Eng. Sci. Res. Technol. 2015, 4, 308-311.

28. Yaqub, M.; Bailey, C. Non-destructive evaluation of residual compressive strength of post-heated reinforced concrete columns. Constr. Build. Mater. 2016, 120, 482-493. [CrossRef]

29. Hertz, K.D. Concrete strength for fire safety design. Mag. Concr. Res. 2005, 57, 445-453. [CrossRef]

30. Lee, J.; Xi, Y.; Willam, K. Properties of concrete after high-temperature heating and cooling. ACI Mater. J. 2008, 105, 334.

31. Ali, F.; Nadjai, A.; Silcock, G.; Abu-Tair, A. Outcomes of a major research on fire resistance of concrete columns. Fire Saf. J. 2004, 39, 433-445. [CrossRef]

32. Peng, G.F.; Huang, Z.S. Change in microstructure of hardened cement paste subjected to elevated temperatures. Constr. Build. Mater. 2008, 22, 593-599. [CrossRef]

33. Arioz, O. Retained properties of concrete exposed to high temperatures: Size effect. Fire Mater. Int. J. 2009, 33, 211-222. [CrossRef]

34. Neville, A.M. Properties of Concrete; Pearson Education Limited: Essex, UK, 2011; Volume 443, p. 444.

35. Chang, Y.F.; Chen, Y.H.; Sheu, M.S.; Yao, G.C. Residual stress-strain relationship for concrete after exposure to high temperatures. Cem. Concr. Res. 2006, 36, 1999-2005. [CrossRef]

36. Hager, I. Behaviour of cement concrete at high temperature. Bull. Pol. Acad. Sci. Tech. Sci. 2013, 61, $145-154$. [CrossRef]

37. Bhardwaj, B.; Kumar, P. Waste foundry sand in concrete: A review. Constr. Build. Mater. 2017, 156, 661-674. [CrossRef]

38. Bradshaw, S.L.; Benson, C.H.; Olenbush, E.; Melton, J.S. Using foundry sand in green infrastructure construction. In Proceedings of the Green Streets and Highways 2010: An Interactive Conference on the State of the Art and How to Achieve Sustainable Outcomes, Denver, CO, USA, 14-17 November 2010; pp. 280-298. 
39. Mavroulidou, M.; Lawrence, D. Can waste foundry sand fully replace structural concrete sand? J. Mater. Cycles Waste Manag. 2019, 21, 594-605. [CrossRef]

40. ASTM C150/C150M-19a Standard Specification for Portland Cement; American Society for Testing and Material: West Conshohocken, PA, USA, 2019.

41. ASTM C33/C33M-18 Standard Specification for Concrete Aggregates; American Society for Testing and Material: West Conshohocken, PA, USA, 2018.

42. ACI Committee. 211.1-91 Standard Practice for Selecting Proportion for Normal, Heavy Weight and Mass Concrete; American Concrete Institute: Farmington Hills, MI, USA, 1999.

43. ACI Committee (American Concrete Institute); International Organization for Standardization. Building Code Requirements for Structural Concrete (ACI 318-08) and Commentary; American Concrete Institute: Farmington Hills, MI, USA, 2008.

44. ASTM C143/C143M-15a. Standard Test Method for Slump of Hydraulic-Cement Concrete; American Society for Testing and Material: West Conshohocken, PA, USA, 2011.

45. BS 1881: Part 103: 1993. Testing Concrete. Part 103. Method for Determination of Compacting Factor (Superseded by BS EN 12350-4: 2000); British Standards Institute: London, UK, 2000.

46. ASTM C C192/C192M-18 Standard practice for Making and Curing Concrete Test Specimens in the Laboratory; American Society for Testing and Material: West Conshohocken, PA, USA, 2012.

47. ASTM C39/C39M-18 Standard Test Method for Compressive Strength of Cylindrical Concrete Specimens; American Society for Testing and Material: West Conshohocken, PA, USA, 2011.

48. ASTM C496/C496M-17 Standard Test Method for Splitting Tensile Strength of Cylindrical Concrete Specimens; American Society for Testing and Material: West Conshohocken, PA, USA, 2017.

49. ASTM C293/C293M-16 Standard Test Methd for Flexural Strength of Concrete (Using Simple Beam With Center-Point Loading); American Society for Testing and Material: West Conshohocken, PA, USA, 2015.

50. Testing Concrete in Structure, Part-2: Non-Destructive Testing, Determination of Rebound Number, Part-4 Determination of Ultrasonic Pulse Velocity; British Standard Institution: London, UK, 2004.

51. Concu, G.; De Nicolo, B.; Pani, L. Non-destructive testing as a tool in reinforced concrete buildings refurbishments. Struct. Surv. 2011, 29, 147-161. [CrossRef]

52. ISO-834-12:2012; Fire Resistance Tests-Elements of Building Construction, Part 12: Specific Requirements for Separating Elements Evaluated on Less Than Full Scale Furnaces; International Organization for Standardization: Geneva, Switzerland, 2012.

53. ASTM E 119-00, Standard Test Method for Fire Tests of Building Construction and Material; American Society for Testing and Material: West Conshohocken, PA, USA, 2012.

54. Guney, Y.; Sari, Y.D.; Yalcin, M.; Tuncan, A.; Donmez, S. Re-usage of waste foundry sand in high-strength concrete. Waste Manag. 2010, 30, 1705-1713. [CrossRef] [PubMed]

55. Prabhu, G.G.; Hyun, J.H.; Kim, Y.Y. Effects of foundry sand as a fine aggregate in concrete production. Constr. Build. Mater. 2014, 70, 514-521. [CrossRef]

56. Siddique, R.; Singh, G. Utilization of waste foundry sand (WFS) in concrete manufacturing. Resour. Conserv. Recycl. 2011, 55, 885-892. [CrossRef]

57. Siddique, R.; Singh, G.; Singh, M. Recycle option for metallurgical by-product (Spent Foundry Sand) in green concrete for sustainable construction. J. Clean. Prod. 2018, 172, 1111-1120. [CrossRef]

58. McCormac, J.C.; Brown, R.H. Design of Reinforced Concrete-ACI 318-11 Code Edition, 9th ed.; John Wiley \& Sons: Hoboken, NJ, USA, 2010.

59. Abrams, M.S. Compressive strength of concrete at temperatures to 1600F. Spec. Publ. 1971, 25, 33-58.

60. Phan, L. Fire Performance of High-Strength Concrete: A Report of the State-of-the-Art; National Institute of Standards and Technology: Gaithersburg, MD, USA, 1996.

61. Purkiss, J.A.; Li, L.Y. Fire Safety Engineering Design of Structures; CRC Press: Boca Raton, FL, USA, 2013.

62. Perkins, P. Repair, Protection and Waterproofing of Concrete Structures; CRC Press: Boca Raton, FL, USA, 2002.

63. Annerel, E. Assessment of the Residual Strength of Concrete Structuresafter Fire Exposure; Ghent University: Ghent, Belgium, 2010.

64. Castillo, C. Effect of Transient High Temperature on High-Strength Concrete; Rice University: Houston, TX, USA, 1987.

65. Poon, C.S.; Azhar, S.; Anson, M.; Wong, Y.L. Strength and durability recovery of fire-damaged concrete after post-fire-curing. Cem. Concr. Res. 2001, 31, 1307-1318. [CrossRef] 
66. Bungey, J.H.; Grantham, M.G. Testing of Concrete in Structures; Blackie Academic \& Professional: Lanarkshire, UK, 1996.

67. Yang, H.; Lin, Y.; Hsiao, C.; Liu, J.-Y. Evaluating residual compressive strength of concrete at elevated temperatures using ultrasonic pulse velocity. Fire Saf. J. 2009, 44, 121-130. [CrossRef]

(C) 2019 by the authors. Licensee MDPI, Basel, Switzerland. This article is an open access article distributed under the terms and conditions of the Creative Commons Attribution (CC BY) license (http://creativecommons.org/licenses/by/4.0/). 